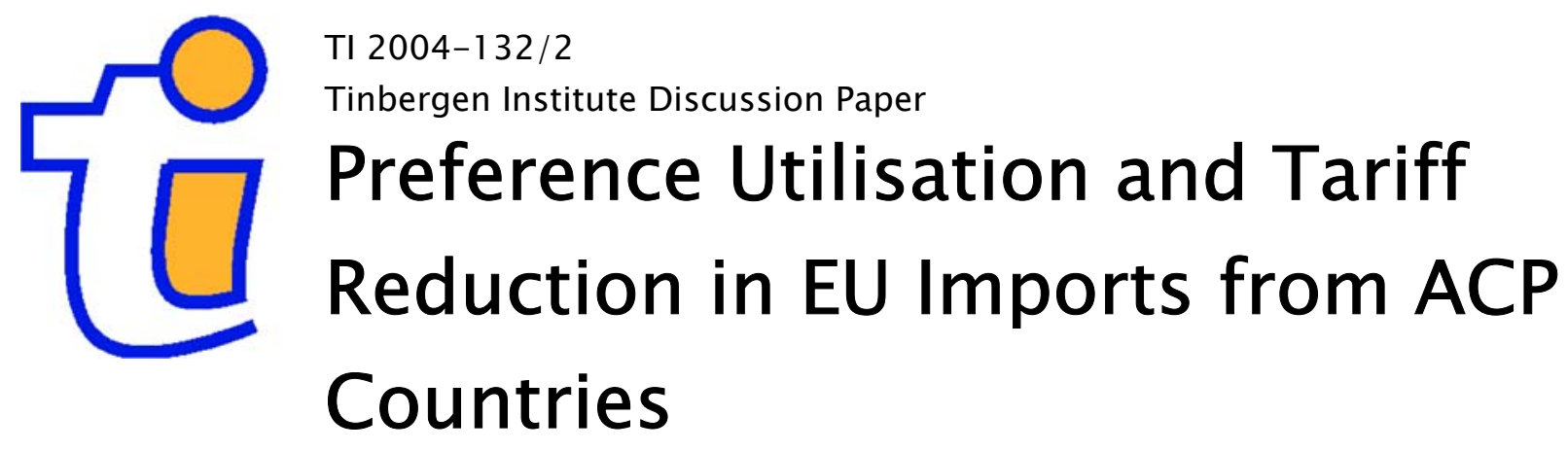

Miriam Manchin

Faculty of Economics, Erasmus Universiteit Rotterdam, and Tinbergen Institute. 
Tinbergen Institute

The Tinbergen Institute is the institute for economic research of the Erasmus Universiteit Rotterdam, Universiteit van Amsterdam, and Vrije Universiteit Amsterdam.

Tinbergen Institute Amsterdam

Roetersstraat 31

1018 WB Amsterdam

The Netherlands

Tel.: $\quad+31(0) 205513500$

Fax: $\quad+31(0) 205513555$

Tinbergen Institute Rotterdam

Burg. Oudlaan 50

3062 PA Amsterdam

The Netherlands

Tel.: $\quad+31(0) 104088900$

Fax: $\quad+31(0) 104089031$

Please send questions and/or remarks of nonscientific nature to driessen@tinbergen.nl.

Most TI discussion papers can be downloaded at http://www.tinbergen.nl. 


\title{
Preference utilisation and tariff reduction in EU imports from ACP countries
}

\author{
Miriam Manchin ${ }^{1}$ \\ Tinbergen Institute, Rotterdam \\ Contact addresses: \\ manchin@few.eur.nl
}

\begin{abstract}
Despite the long relationship between the EU and the African, Caribbean and Pacific (ACP) countries aimed at encouraging their exports while stimulating growth and investment, the ACP states still face difficulties in integrating into the world economy. This paper examines the non-least developed ACP countries preferential trade with the EU. The objective is to explain the determinants of preferential exports of ACP countries towards the EU and to assess the impact of preferences on trade volumes. We also investigate the existence of a threshold in the offered duty reduction under which traders have no incentives to ask for preferences.
\end{abstract}

\footnotetext{
${ }^{1}$ I am thankful for helpful comments from Paul Brenton, Joe Francois and Eric Strobl. I am also thankful to Micheal Henry for providing me with programs for the threshold estimations.
} 


\section{Section 1: Introduction}

Economic and trade co-operation play an integral part of the EU policy towards African, Caribbean and Pacific (ACP) countries, dating back as early as the treaty of Rome (1957). However, despite benefiting from one of the most generous trade preference scheme of the EU providing free access (subject to rules of origin) for $95 \%$ of their exports, it is a generally accepted view that the ACP countries have been unsuccessful in taking advantage of their preferential status and, indeed, performed poorly in comparison with other developing countries (McQueen, et al. (1997)). For instance, the share of world exports of ACP countries fell from $3.4 \%$ in 1976 to $1.9 \%$ in 2000 and their share in developing countries exports from $13.3 \%$ in 1976 to $3.7 \%$ in 2000 . Their trade patterns with the EU has followed a similar evolution: the share of EU imports from the ACP in total EU imports has decreased, falling from $6.7 \%$ in 1976 to $3.11 \%$ in 2002, and the share of imports from the ACP in total imports from developing countries (excluding countries in transition) has fallen from $14.8 \%$ in 1976 to $6 \%$ in $2000 .^{2}$ Davenport, Hewitt and Koning (1995) also point out that, despite the number of Lomé beneficiaries increasing from 46 countries to 69 countries over the period 1975-92, the share of ACP non-oil-exports in EU imports declined from 6.1\% to $2.9 \%$, and compared to other developing countries with less preferential access to the European market, the deterioration in the ACP performance is even more pronounced. Successful experiences of the preference utilisation are restricted to certain sectors and countries (ECDPM (2001a).

Due to these inefficiencies in delivering improved market access, changing geopolitical interests and other political factors, the EU relationship with the ACP came under growing pressure (ECDPM (2001b)), and as a result new Partnership Agreement was signed in Cotonou. Under the Cotonou Agreement current non-reciprocal trade preferences will be maintained temporarily up to 2008 and new reciprocal trade agreements will be negotiated and implemented gradually. The main objective of the economic and trade co-operation signed in Cotonou is to promote gradual integration of the ACP States into the world economy and support their sustainable development as well as enable the ACP States to manage their transition to the liberalised global economy (ECDPM (2001c)). In order to achieve these objectives, it is essential to understand the main determining factors of the utilisation of trade preferences.

\footnotetext{
${ }^{2}$ Source: European Commission, http://europa.eu.int/comm/trade/issues/bilateral/regions/acp/index_en.htm.
} 
Nevertheless, there is very little ex-post evidence on the effects of preferential schemes on the export performance of the beneficiaries. The empirical literature on preference schemes highlights several difficulties limiting the benefits available for the recipient countries. Some papers pointed out that administrative requirements and technical requirements (such as rules of origin) of preferential programs often impose considerable burden on traders, especially on lesser-developed countries, resulting in low utilisation rates of the preferences. ${ }^{3}$ Certain preference schemes, such as the GSP preferences of the US, are limited to some sectors, in which developing countries lack comparative advantage $^{4}$ (only 53 per cent of dutiable imports from developing countries are eligible for preferences under the US's GSP ${ }^{5}$ ). When the preference schemes include export ceilings these are often binding. ${ }^{6}$ Özden and Reinhardt (2004) find that countries dropped from the US's GSP scheme subsequently adopt lower trade barriers than those remaining eligible. The authors conclude that full integration into the reciprocity-based world trade regime rather than continued GSP-style preferences would be more beneficial for developing countries.

The current paper explicitly examines the non-least developed ACP countries' preferential trade with the EU. Our objective is to explain the determinants of preferential exports of non-least developed ACP countries towards the EU and to assess the impact of preferences on trade volumes. The paper also investigates if there exists a threshold in the offered duty reduction under which traders have no incentive to ask for preferences since the costs of obtaining these exceeds their benefits. One should note, that while there are currently two preferential schemes available for these countries - the Generalised System of Preferences (GSP) and the Lomé preferences which were recently revised under the Cotonou Agreements -our empirical analysis mainly concentrates on the Cotonou preferences due to the limited utilisation of the GSP preferences by this group of countries, although we do compare the two schemes.

The next section of the paper explains the historical evolution of the two preferential schemes. The third section looks at the importance of the preferences in terms of coverage, tariff reductions and utilisation rates. The paper then provides a quantitative assessment of the impact of preferences using Heckman sample selection and threshold estimation techniques. The final section of the paper concludes.

\footnotetext{
${ }^{3}$ UNCTAD (1999, 2000), Brenton and Manchin (2003), Falvey and Reed (2002), Krishna and Krueger (1995), Cadot, et al. (2003).

${ }^{4}$ Devault (1996).
} 


\section{Section 2: EU-ACP relations}

\section{Lomé}

The first agreement between the European Economic Communities (EEC) and the ACP countries dates back to 1963 when the "Yaoundé Agreements" were signed which was in effect between 1963 and 1975. The objective of the agreement was to foster economic cooperation between the EU and ACP countries. The most important part of the resources was directed towards francophone Africa to build up infrastructure during the decolonization. After the United Kingdom joined the EEC, the Lomé I Agreement was singed and was in force between 1975 and 1980 including 46 ACP countries and the EEC Member States. At the same time, the ACP countries joined together to form the ACP with the completion of the Georgetown Agreement. The first Lomé Agreement introduced trade preferences for most ACP exports to the EEC. Special trade protocols were introduced for sugar, bananas, beef and veal. These trade preferences and protocols were extended for further periods under successive Lomé Conventions (Lomé II (1980-85), Lomé III (1985-90) and Lomé IV (1990-2000)). The banana protocol gives duty-free entry for specific quotas of bananas into the EU market. Under the sugar protocol, EC annually buys a fixed quantity of sugar from ACP producers at its internal sugar price. Among the major beneficiaries of this arrangement are Mauritius, Fiji, Guyana and Barbados. Under the beef and veal protocol, the EC refunds 90 per cent of tax normally paid on beef imports from several ACP countries. This has been especially beneficial to Southern African exporters (Panagariya (2002)).

The scope of the Lomé Convention covers more than just trade preferences, incorporating even environmental and human rights considerations. After the expiration of the Lomé IV a new Partnership Agreement with the ACP states was signed in Cotonou in 2000. The agreement's key objective is poverty reduction and bringing more stability in the region. According to a Press release of the EC: "Focusing on poverty reduction as its principal objective, to be achieved through political dialogue, development aid and closer economic and trade cooperation, this agreement will shape a significant part of the European Union's dealings with the rest of the world." ${ }^{7}$ The agreement is for a 20-year period. The trade relationship between EU and ACP partners is intended

\footnotetext{
${ }^{5}$ The information here comes from UNCTAD (2001).

${ }^{6}$ MacPhee and Rosenbaum (1989), Hoekman and Kostecki (2001).

${ }^{7}$ Press release IP/00/640 Brussels, 21 June 2000, The European Community and its Member States sign a new Partnership Agreement with the African, Caribbean and Pacific states in Cotonou, Benin
} 
to change gradually. During 2000-07, which is regarded as the preparatory period, the current regime with its preferences and the protocols on sugar, banana, and beef and veal are to be maintained in some modified form. In parallel, countries other than the least developed countries are to negotiate economic cooperation agreements under which current one-way trade preferences by the EU will be replaced by reciprocal preferences more or less as in the case of the Mediterranean partners. The new arrangements are to enter into force latest by January 1, 2008, with transition to a full FTA spread over at least 12 years.

\section{GSP preferences}

While being beneficiaries of the Cotonou Agreements, ACP countries are eligible also for GSP preferences. In 1968, UNCTAD recommended the creation of a 'Generalised System of Preferences' (GSP) under which industrialised countries would grant autonomous trade preferences to all developing countries and the waiver to allow such preferences was granted in 1971 by the GATT. The GSP preference scheme provides nonreciprocal preferences with lower tariffs or completely duty-free access for imports from 178 developing countries and territories into the EU market. GSP preferences are not part of contractual agreements with the recipient countries. ${ }^{8}$ The general arrangements cover roughly 7000 products, of which 3250 are classified as non-sensitive and 3750 are classified as sensitive products. The tariff preferences offered by the general arrangements differ according to the sensitivity of the products concerned: non-sensitive products enjoy duty free access to the EU market, while sensitive products benefit from a tariff reduction. These arrangements provide, as a rule, for a reduction of MFN ad valorem duties by a flat rate of 3,5 percentage points. An important exception to this rule of a flat rate reduction is granted to the textiles and clothing sectors which enjoy a percentage reduction of $20 \%$. For specific duties a percentage reduction of $30 \%$ is the general rule. Where duties include ad valorem and specific duties, only the ad valorem duties are reduced.

A special arrangement under the Everything but Arms (EBA) initiative, which is incorporated into the GSP preference scheme, is provided for least developed countries (LDCs). The EBA scheme provides duty-free access for all products covered and originating in the beneficiary country, with

\footnotetext{
${ }^{8}$ A new GSP regulation, the third of the 10-year cycle, (Council Regulation (EC) No 2501/2001 as last amended by C Council Regulation No 2211/2003) implements the current scheme from 1 January 2002 to 31 December 2005. New guidelines for the next 10-year cycle 2006-2015 are currently being prepared.
} 
the exception of imports of fresh bananas, rice, and sugar. ${ }^{9}$ This scheme is more generous in terms of duty reduction than the Cotonou scheme; however in some other aspects, such as cumulation rules, it is less generous.

\section{Section 3: Importance of preferences for ACP countries}

In order to examine the relationship between trade and preferential treatment we use information of EU member states' imports eligible for preferences under the Cotonou agreement for the period 2001 from non-least developed ACP countries at the 8-digit level. This raw trade data was obtained from Eurostat and includes both total imports from ACP countries and imports requesting preferential treatment. Using information on tariffs and preferential quota applicable on each 8-digit product for the year 2001 we then identified those products which were eligible for preferences and calculated the ad-valorem tariff rates.

Figure 1 shows the developments of EU imports from non-least developed ACP countries during the last decade. ${ }^{10}$ While the value of the imports had been increasing during the period, the share of imports from these countries in total EU imports had been decreasing.

Table 1 demonstrates which export schemes were used by the different countries. ${ }^{11}$ It is apparent from the table that GSP preferences were requested only by a few countries (mainly by South Africa, Swaziland, and Namibia) and only to a limited extent. The share of exports that requested GSP preferences in total exports for the country group was around 6\%. Instead ACP countries tended to use Cotonou preferences rather than GSP preferences; the utilisation rate (share of exports that requested preferences in total exports) of Cotonou preferences was close to $50 \%$. However, there are important differences between countries in the utilisation rate. While certain countries, such as Senegal, Seychelles, Dominica, Cameroon etc, have high utilisation rates, several countries utilise the Cotonou preferences only limitedly.

\footnotetext{
${ }^{9}$ For a detailed discussion on the impact of EU preferences for LDCs under Everything But Arms see Brenton (2003).

${ }^{10}$ Nauru, Niue and the Cook Islands were not included in the analysis due to data limitations.

${ }^{11}$ The columns of the table show the share of exports which requested Cotonou or GSP preferences. The preferential access actually granted might be less than these figures, thus the table could overstate the actual utilisation of the preferential schemes.
} 
The significant difference between requesting GSP and Cotonou preferences may reflect that for most of the products exported by the ACP countries the Cotonou scheme offers better access. One important difference between the two schemes is in the rules of origin. Rules of origin define the conditions that a product must satisfy to be originating from the exporting country which asked for the preferential access. The main justification for rules of origin is to prevent trade deflection, whereby products from non-participating countries destined to the free trade area partner are redirected through the other free trade partners to avoid the payment of customs duties. When products are produced in a single stage then the origin of the products should be relatively easy to establish. For all other cases the rules of origin define the methods by which it can be determined that the product has been sufficiently processed in the free trade partner to qualify for preferential access. The specification of rules of origin has become especially important in recent years as technological progress and globalisation have led to the increasing fragmentation of the production process into different stages or tasks which are undertaken in different locations.

There are different methods used to determine whether preferential access can be granted. The simplest way of defining origin is probably change of tariff heading, alternatively there can be rules relating to the amount of domestic value-added or to specific technical requirements that the product may satisfy. The basic rule used in the EU's bilateral trade agreements is that of the change in tariff heading at the 4-digit level of the Harmonised System of tariff classification. However, in a very large number of cases this basic rule is replaced by specific requirements. These other requirements can be a minimum percentage of local value added in the originating country, or a technical requirement that requires that the product undergoes specific manufacturing operations in the country. Several empirical studies found that the level of restrictiveness of the rules of origin depends on the method used for defining origin and it influences the utilisation of preferences (Augier et al. (2005), Estevadeordal and Suominen (2005)). Carrère and de Melo (2004) find that compliance costs are the least for a change of tariff classification, followed by regional value content and by technical requirements.

One notable difference between the Cotonou and the GSP preference scheme's rules of origin is in the cumulation rules. When cumulation is allowed materials used from other countries during the production can be regarded as originating materials. Different levels of cumulation are used in free trade agreements. The most advanced form of cumulation is full cumulation allowing for any processing (even if it does not confer origin) carried out in any participating country to be carried 
on to another partner country and counted as if it were undertaken in the country of final processing. A stricter form of cumulation is diagonal cumulation which allows qualifying materials from any participating country to be used in the processing in another participating country and counted as if it were done in the country of final processing. The difference between diagonal and full cumulation is that under the diagonal cumulation the input used from another participating country has to be qualifying, in other words it has to meet the rules of origin requirements. Finally the bilateral cumulation allows cumulation only between the two partner countries, and does not allow regional cumulation. While the Cotonou Agreement allows full cumulation ${ }^{12}$, the GSP scheme allows diagonal cumulation within only four regions (ASEAN, CACM, the Andean Community and SAARC). Since non of the non-least developed ACP countries are members of these regional groups, diagonal cumulation is not available under the GSP scheme for these countries.

Another difference is in the minimum processing or tolerance rules between the two preferential schemes. While under the GSP scheme non-originating inputs can be used given that their value does not exceed 10 per cent of the ex-works price of the product, under Cotonou, non-originating materials up to a total value of 15 per cent of the ex-works prices can be used (Brenton (2003)).

The first column of Table 2 shows the total exports of countries to the EU. The second column of the table shows the share of exports where the applicable MFN tariff rate was zero. Around $64 \%$ of the exports from these countries entered into the EU with zero MFN tariffs, although there are important differences between countries. This implies that for several countries the trade preferences provided by the EU offered only limited benefits. The third column of the table shows the share of exports excluded from the preferences, which was around $4 \%$ of exports in 2001 . There were again substantial differences between countries; while, for example, 92\% of Fiji's exports were excluded from preferences, in the case of Botswana no exports were excluded from the preferences. The final column presents the share of exports eligible for preferences, which for the country group as a whole was around 31\%. Although the preferential scheme seems to be significant for several countries, some countries trade mainly in products where the MFN tariffs were already reduced to zero limiting the impact of Cotonou preferences on these countries' trade.

\footnotetext{
${ }^{12}$ There is no additional requirement on the value-added in the final stage relative to the inputs used with the exception of South Africa, for which the value-added has to exceed the value of materials from South Africa.
} 
Table 3 depicts the utilisation rate of Cotonou preferences and the average difference between MFN and preferential duties under Cotonou by sector. The difference between preferential and MFN tariff rates was the smallest for machinery and mineral products, where on average the difference between MFN and ACP preferential tariff is 3\%. Furthermore the utilisation rate in these two sectors is also smaller than in most of the sectors, although there is an important difference between the two sectors since utilisation is much higher in machinery than in mineral products. The sectors where the utilisation rate was the highest are wood, clothing, textiles, and agriculture.

\section{Section 4: Econometric Model}

This part of the paper examines empirically the driving factors for requesting preferential treatment for exports, and the impact of preferences on trade volumes. The analysis is limited to the exports which are eligible for preferences.

\section{Methodology}

The importer's decision whether to request preferential treatment or not and how much to import could be differently influenced by the preferences offered, the determinants of trade, and some other factors. While some factors might be important in the decision on how much to import, the same factors might be less important when the trader decides whether he requests preferences or not. However these two decisions are linked: only if preferences were asked can preferential imports be observed. Employing a sample selection model would allow one to take account of this censoring process. More precisely, in the sample selection model the outcome variable (the dependent variable in the second stage equation) is only observed if the defined selection criterion is met. In our case, the level of the utilisation rate (the share of imports that requested preferential treatment in total trade) is only observed if preferences were requested.

Here we employ the widely used Heckman sample selection model. Heckman's sample selection model is based on the following two latent variable models:

$$
\begin{aligned}
& \mathrm{Y}_{1}=\alpha^{\prime} X+\mathrm{u}_{1} \\
& \mathrm{Y}_{2}=\beta^{\prime} Z+\mathrm{u}_{2}
\end{aligned}
$$


where $X$ is a $k$-vector of regressors, $Z$ is an $m$-vector of regressors, and $\mathrm{u}_{1}$ and $\mathrm{u}_{2}$ are the error terms which are jointly normally distributed, independently of $X$ and $Z$, with zero expectations. The variable $Y_{1}$ is only observed if $Y_{2}>0$. The variable $Y_{2}$ takes the value of one if $Y_{1}$ is observed, while it is 0 if the variable $Y_{1}$ is missing. In our regressions $Y_{1}$ is the value of imports that requested preferences, while $Y_{2}$ is a dummy variable taking the value one if preferences were requested. Thus in our setting the first equation captures how the probability of asking preferential treatment for exports is influenced by different factors, while the second equation shows how the value of preferential imports is affected given that preferences were requested. The variables specified in the first equation are assumed to determine whether the dependent variable in the second equation is observed.

A first problem that arises in employing the model above to the issue at hand is that (1) is a probit model where the dependent variable needs to take either the value zero or one, depending on whether preferences were requested or not. Normally, one would simply construct a variable taking on the value of one where there are positive utilization rates and zero otherwise. Thus the dichotomous variable takes the value of one if all of the traders requested preferences, but it also takes the value of one if only a single trader requested the preferences and all the others did not. ${ }^{13}$ However, the raw data indicates that there are some individual traders who ask for preferential treatment when it does not seem reasonable to do so, which would result in falsely assigning the value of one to the dependent variable in the selection equation. In particular, there are two cases which one could argue it is unreasonable to ask for preferences. Firstly, preferences are sometimes requested even when there are no preferences available. One possible explanation for these might be lack of information. Some traders might not have sufficient information about changes introduced to the preference scheme or general trading conditions - for example the trader might not be informed about the abolition of MFN tariffs on a specific product. Further, certain traders might have limited knowledge about the preference scheme at product level while being informed about the existence of the preference program. To deal with this aspect we include observations for which imports are eligible for preferences. Secondly, even if preferences are available it may still be unreasonable that traders requested these. More precisely, since requesting preferences is a costly procedure, even if preferences are available, if the value of the preferences does not exceed those of the costs of getting the preferences a trader should have no incentive to ask for them. Such

1. ${ }^{13}$ This is because our data contains information on imports by 8-digit product categories for each country, but it does not contain detailed data by individual traders. Therefore for each product we have information on the 
costs occur because of both technical and administrative difficulties in complying with the rules of origin (for a detailed discussion on the role of rules of origin in the EU trade agreements see Brenton and Manchin (2003)). Therefore it is more reasonable to expect that there is a threshold value or switching point in the value of preferences offered, below which it would not be worth asking for them. The fact that there are some traders who request preferences when benefits seem to be very limited might occur when, for example, costs for traders are limited due to economies of scale, corruption or for some other reasons, or costs are measurable only ex-post.

Thus, for this latter case in order to avoid that such "outlier" traders influence the results, as a first step we first seek to identify a possible threshold value in the preferences offered (measured by the difference between third country MFN tariffs and preferential tariffs) by the EU for the decision whether to ask for preferential treatment or not. The existence of such threshold or switching point would confirm our prior that there is a minimum level of reduction in the tariffs until which it is not worth asking for the preferential treatment. It would also allow us to treat any what appear to be unreasonable positive utilisation rate values appropriately as zeros for the first step of the selection model outlined above.

Table 4 shows the utilisation rate of Cotonou preferences by difference between MFN and preferential duty. There seems to be an intuitive relationship between the utilisation of preferences and the value of preferences offered: a higher uptake of preferences seems to correspond to higher rate of duty reduction. Moreover, there appears to be a clear structural break in the relationship between the rate of utilisation and the value of the preferences involved when the difference between MFN and ACP preferential tariff is 3-4 per cent.

Since there may be other factors influencing the decision to ask for preferences we employ the technique recently developed by Hansen to endogenously determine any threshold in the relationship of interest, which allows one to control for such other factors. More specifically, this threshold estimation technique is ideal when data needs to be split into subsamples in consideration of some relationship of interest. It takes the following form:

$$
y_{i}=\beta_{1}^{\prime} x_{i}+e_{i}, q_{i} \leq \gamma
$$




$$
y_{i}=\beta_{2}^{\prime} x_{i}+e_{i}, q_{i}>\gamma
$$

where $\mathrm{q}_{\mathrm{i}}$ is the threshold variable and $\gamma$ is the threshold parameter which splits the sample into two subsamples. The threshold parameter can be determined endogenously by allowing the continuously distributed $\mathrm{q}_{\mathrm{i}}$ to be an element of $\mathrm{Xi}$. This model allows the regression parameters to differ depending on the value of $q_{i}$. The model can be re-written into a single equation:

$$
y_{i}=\beta^{\prime} x_{i}+\delta_{n}^{\prime} x_{i}(\gamma)+e_{i}
$$

where $\beta=\beta_{2}$ and $x_{i}(\gamma)=x_{i} d_{i}(\gamma)$, and $d_{i}(\gamma)=\left\{q_{i} \leq \gamma\right\}$ is a dummy variable.

The first step is to identify the threshold value $\gamma$ and the other coefficients. This is done by using the algorithm provided by Hansen (2000), which searches through the values of $\gamma$ until the splitting value is found (this is the value of $\gamma$ which minimises the concentrated sum of squared errors based on an OLS regression). To test the significance of the threshold value Hansen (2000) recommends a bootstrap procedure based on a likelihood ratio (LR) test, since under the null hypothesis of no threshold effect the threshold is not identified.

\section{Empirical Model}

Having outlined our econometric approach we now proceed to describe our exact empirical specification. Our choice of variables is guided by the existing empirical literature on the determinants of trade. We use a gravity framework according to which bilateral trade should be positively related to the partner countries' income and size and negatively related to trade costs. The gravity model is a well-known and widely applied model of bilateral trade flows. On the theoretical framework of the gravity-models see Deardorff (1995) or Anderson and van Wincoop (2003). In terms of our Heckman selection model we estimate the following:

$\ln X_{i j}=\alpha+\beta_{1} \ln G D P_{i}+\beta_{2} \ln P O P_{i}+\beta_{3} \ln G D P_{j}+\beta_{4} \ln P O P_{j}+\beta_{5} \ln D_{i j}+$

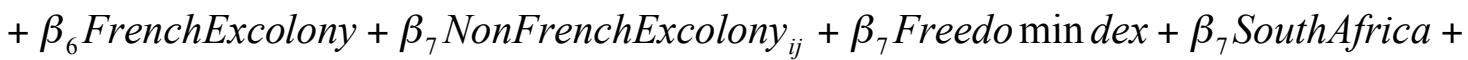

$+\beta_{8}$ dutydifference $+\sum_{i j k} \gamma_{i j k} D U M_{i j k}+u_{1}$ 
and we assumed that $\mathrm{X}_{\mathrm{ij}}$ is observed if

$\alpha^{\prime}+\chi_{1} \ln G D P_{i}+\chi_{2} \ln P O P_{i}+\chi_{3} \ln G D P_{j}+\chi_{4} \ln P O P_{j}+\chi_{5}$ Freedo $\min$ dex +

$+\chi_{6}$ FrenchExcolony $_{i j}+\chi_{7}$ NonFrenchExcolony $+\chi_{8} \ln$ PREF $+\chi_{9}$ SouthAfrica +

$+\sum_{i j k} \lambda_{i j k} D U M_{i j k}+u_{2}>0$

and $u_{1}$ and $u_{2}$ have correlation $\rho$.

$\mathrm{X}_{\mathrm{ijk}}$ is the utilisation rate of Cotonou preferences for product $\mathrm{k}$, in other words the percentage of country $i$ 's imports of product $\mathrm{k}$ from country $j$ which requested preferential access. The data originates from Eurostat and contains import data at 8-digit level for the year 2001.

As a proxy for the trading countries' income and size the GDP $\left(\mathrm{GDP}_{\mathrm{i}}\right.$ is the level of income in country $I$ ) and population ( $\mathrm{POP}_{\mathrm{i}}$ is the population in country $\mathrm{i}$ ) of both partner countries are included in the regression. GDP and population data is taken from the World Development Indicators database.

$\mathrm{D}_{\mathrm{ij}}$ is distance between the partner countries proxying trading costs. Previous empirical results showed that distance had an important negative impact on trade. The further away the trading partners are located from each other the higher the costs will be for transporting the products. Distance is thus also included in our regression and is expected to have a significant and negative impact on preferential trade. The distance data originates from the CEPII distance database and calculated following the great circle formula, which uses latitudes and longitudes of the capital cities.

To investigate the importance of the quality of economic environment in a given exporting ACP country an indicator of economic freedom was used (Freedomindex). The index was obtained from the Freedom House "Freedom in the World Countries" database ${ }^{14}$. "Freedom in the World Countries" is a database containing an annual comparative assessment of the state of political rights and civil liberties in 192 countries and 18 related and disputed territories. The lower is the index the more economic freedom the country has. We expect that countries with greater economic freedom are more open and more likely to trade.

\footnotetext{
${ }^{14}$ See further details on the methodology of the index: http://www.freedomhouse.org/research/freeworld/2003/methodology.htm.
} 
To capture historical linkages between trading partners two zero-one type dummy variables were included in the regression. FrenchExcolony $y_{i j}$ and NonFrenchExcolony $y_{i j}$ take the value of 1 if the exporting country (i) was a colony of France or other partner country(j). Colonial links often reflect not only historical ties but also that the traders of the two partner countries can speak the same language. If a country was an ex-colony of its trading partner trade between the two countries would probably necessitate lower transaction costs thus more trade. A separate dummy is included for non French ex-colonies and French ex-colonies, because we expect that there might be differences in the intensities of the trade links for French ex-colonies. ${ }^{15}$

A variable measuring the hypothetical value of preferences (PREF), which is the difference between the third country duty and the preferential duty multiplied by eligible imports, was included in equation (7). This variable allows us to take into account the importance of the EU's preferential treatment on its bilateral trade with ACP countries. This variable captures the potential value of the preferential scheme if all eligible trade would have requested and obtained preferential treatment. Given that the preferences were not usually fully utilized in most of the cases, the real value of the preferences is almost always lower than the 'hypothetical' value of the preferences. To construct the variable the difference between the third country duty and the preferential duty payable was calculated and multiplied by all eligible trade. The data on preferential and MFN tariffs were obtained from the European Commission.

In many aspects, such as size of the economy or the level of development, South Africa differs from most of the other countries in our sample. In order to avoid that specificities of South Africa is driving our results a dummy taking the value 1 if the exporting country is South Africa is included in the regressions. Dutydifference $e_{\mathrm{k}}$ is the difference between MFN and preferential tariffs for product $\mathrm{k}$. DUM $\mathrm{ijk}_{\mathrm{ijk}}$ are a set of $k$ dummy variables for agriculture, textiles, clothing, footwear, machinery and mineral products. ${ }^{16}$

Equation (6) assesses the determinants of the preferential trade and shows the main factors influencing the amount of utilisation rate, given preferences were requested. In equation (7), which sets out the selection criteria and provides information on the factors which influences the decision

\footnotetext{
${ }^{15}$ Only four countries were not colonies in our sample.

${ }^{16}$ From the 23685 observations 9015 is not covered by any sectoral dummies, these observations belong to sectors such as metals, vehicles, optics, chemicals, plastics, stones, and glasses.
} 
whether to request preferences or not, distance is not included. This is because distance proxies transport costs, and while it might influence the value of preferential trade, it is unlikely to influence the decision whether preferences are asked for or $\operatorname{not}^{17}$. The threshold value obtained from the threshold regressions was used to construct the selection criterion. The dependent variable in equation (7) takes the value 1 if the difference between preferential and MFN duty is above the threshold and preferences were requested, while taking on the value of 0 otherwise.

In order to create the zero-one dependent variable in (7) we estimated the following equation to identify the threshold value of preferential treatment:

$$
\begin{aligned}
& \ln X_{i j k}=\alpha+\beta_{1} \ln G D P_{i}+\beta_{2} \ln P O P_{i}+\beta_{3} \ln G D P_{j}+\beta_{4} \ln P O P_{j}+\beta_{5} \ln D_{i j}+ \\
& +\beta_{6} \text { FrenchExcolony } \beta_{7} \text { NonFrenchExcolony }{ }_{i j}+\beta_{7} \text { Freedo min dex }_{+} \beta_{7} \text { SouthAfrica }+ \\
& +\beta_{10} \text { dutysmall }_{k}+\beta_{11} \text { dutyhigh }_{k}+\beta_{12} \text { quota }_{k}+\beta_{13} \text { difference }_{k}+\sum_{i j k} \gamma_{i j k} D U M_{i j k}+u
\end{aligned}
$$

Most of the explanatory variables in equation (8) were also used for the Heckman estimation. The variable dutysmall is a dummy variable that takes the value of one if the difference between MFN and preferential duty was smaller than the threshold. Similarly, the dummy variable dutyhigh takes the value of 1 if the difference between tariff rates is higher than the threshold. Two further dummies were included in equation (8). Quota ${ }_{k}$ is a dummy which takes the value 1 if the product was eligible for quota preferences and zero otherwise. The dummy for quota is included in the regression because it is likely that the circumstances for products entering under a preferential quota are different than for products entering without quota preferences; for example traders using the quota preferences are likely to be better informed. Furthermore, we include a dummy (called difference) for agricultural products for which the difference between preferential and MFN tariffs exceeds $30 \%$. These agricultural products benefit from seasonal preferential duty reduction. Since we have yearly data it was not possible to exactly calculate the tariff reduction for these products, we calculated the yearly average tariffs, which might overestimate duty reduction. Although these products only represent $0.8 \%$ of all observations to avoid that it inflates the threshold estimation we include a dummy for these products.

\footnotetext{
${ }^{17}$ To check this we run the regressions including distance also in the first stage equation, however distance was never significant.
} 


\section{Section 5: Empirical Results}

\section{Threshold Estimation Results}

In employing our threshold estimation one cut-off value was identified, which corresponds to the value when the difference between MFN and preferential tariff is 0.045 (which is $52^{\text {nd }}$ percentile) in other words, it corresponds to a preferential tariff which is $4.5 \%$ lower than third country tariffs. The $95 \%$ confidence interval for the threshold estimates is obtained by plotting the likelihood ratio sequence in $\alpha$ (the percentiles of the duty difference variable), $\operatorname{LR}(\alpha)$, against $\alpha$ and drawing a flat line at the critical value (the $95 \%$ critical value is 7.35 ). The part of the curve, which is below the flat line, will be the confidence interval for the threshold estimate. Figure 1 shows that at the 95\% confidence interval the threshold obtained is between 48 and 52 percentiles or in terms of tariff difference is between 4 and $4.5 \%$. This confidence interval is plausibly tight, since it has only 341 observations out of 23685 observations falling within the $48^{\text {th }}$ and $52^{\text {nd }}$ percentiles. To test the robustness of our results, we re-run the threshold regressions including country specific dummies instead of country specific variables. We obtain the same threshold values for this specification as well (the threshold value found to be at the level when preferential tariff is lower than MFN tariff by $4 \%)$.

One should note that this finding is in line with some previous estimates found on the costs of obtaining preferences. Herin (1986) estimates that the costs of documentation and the administration of origin rules, which is the principal part of increased costs for preferential trade, impose costs on exporters equivalent to some $3 \%$ of the value of the goods traded in the case of EFTA countries. For ACP countries these costs are expected to be even higher, due to information disadvantages, institutional difficulties etc. Carrère and de Melo (2004) provide non-parametric estimates for compliance costs of rules of origin based on the average rate of tariff preference for NAFTA. The authors obtain that the average total compliance costs for 2001 was $6.16 \%$. When using double-censored tobit estimation techniques the authors find a compliance cost estimate of $3.86 \%$ for products with a utilization rate higher than $0 \%$ and smaller than $100 \%$.

In order to verify that the threshold value identified is correct a probit regression was undertaken using the identified threshold value. The existence of the threshold implies that the relationship between duty reduction and utilisation rate is constant among sub-sets of the products but varies 
between products. For products for which the duty reduction is only limited the utilisation rate might not be significantly influenced by the preferences offered, while higher duty reduction should significantly increase utilisation rate. Thus if the threshold value is correct, the duty reduction under the threshold should not significantly influence utilisation rate. Table 6 shows the results of the probit regression. Both the results of equation (1) and (2) confirm the threshold value. The coefficient of the variable measuring the difference between preferential and MFN duty is negative and insignificant when it is below $4.5 \%$ (dutysmall), while when the duty difference is above the threshold (dutyhigh) it increases the probability of utilising the preference scheme. These results confirm that the threshold value was correctly identified, in that there exists a different relationship between the tariff reduction above of the threshold and the uptake of preferences.

\section{Sample Selection Model Results}

In terms of estimating the selection model in equation (7) we used as the dependent variable a zeroone variable which takes the value of one if preferences were requested and the duty difference was higher than $4 \%$, as indicated by our threshold estimation. This includes $70 \%$ of observations which requested preferences; in $30 \%$ of the cases when preferences were requested by traders the duty difference was below $4 \%$. The average utilisation rate is $16 \%$ when the duty difference is less than $4 \%$ and $43 \%$ when it is more. Therefore by using the results of the threshold value for determining the selection criteria some observations are set equal to zero where only a small share of (nonrational) traders requested preferences.

Regression results are presented in Table 7, 8 and 9. The variables GDP and population are highly correlated (Table 11 shows the pairwise correlation coefficient between variables). Furthermore distance is highly correlated with GDP/POP. Therefore we proceeded by employing specifications where we included these variables separately. The first column includes only GDP of both countries, the second contains GDP divided by population, while the third contains GDP and population separately. Column 4 contains country specific dummy variables allowing one to capture country specific characteristics which might be omitted with the previous specifications. The final column uses country specific dummies and sectoral variables measuring the impact of preferences in each sector. While the results presented in Table 7 and 8 include sectoral dummies only for the selection equation, Table 9 presents results where sectoral dummies were included in both stages. 
In terms of our control variables it can be seen that the coefficient of the distance variable is significant and negative in all equations except when country specific dummies are included (equation (4) and (5)) when it becomes insignificant and positive. The variable Preferences, which measures the hypothetical value of preferences, is significant and has a positive sign implying that the higher the value of the preferences the more likely that traders request preferential treatment. However, the amount of duty reduction (the difference between preferential and MFN tariffs) does not have a significant effect on the amount of utilisation. In other words, while the value of preferences influence whether preferences are requested or not, once this decision has been made, the duty reduction does not influence any more how much preferential trade is requested.

The variable measuring the economic freedom of the ACP countries is highly correlated with their GDP, income per capita, and distance (the correlation coefficients with income with income per capita, and with distance are $-0.19,-0.24$, and -0.56 , respectively). In the first and third column the freedom index is significant and negative when distance is not included in the regression (selection equation). In the second column, when income per capita was included instead of GDP, the freedom index variable was significant and positive, which might be the result of high correlation between income per capita and the economic freedom of the country. Nevertheless the results suggest that the higher the economic freedom the more likely that the traders of the country request preferential treatment.

All the sectoral dummies included in the regressions are significant, and indicate that there are important differences between different sectors. Two sectoral dummies, machinery and minerals have negative coefficients, implying that exports in these sectors have a lower probability of requesting preferences given the value of these. Textiles, clothing and agriculture are the sectors where there is the highest probability of requesting preferential market access to the EU.

In columns 4 and 5 country specific dummies are included instead of country specific variables. As can be seen, the results of the former are similar to the previous results, although the coefficients of the explanatory variables are slightly smaller than in the previous equations. In the fifth column, instead of including the variable measuring the hypothetical value of preferences and sectoral dummies separately, variables measuring the preferences by sector were included, proxied by the products of the Preference variable and industry dummies. For all sectors the preference scheme had a positive impact on the uptake of preferences, although with important differences between the 
sectors. The offered preferences had the highest impact for textiles, machinery and clothing products. The sector where the preferences had the lowest effect on the uptake of preferences was minerals, which might reflect the low duty reductions provided for this sector under the preference scheme.

Table 10 presents the results of the Heckman regression without using the results of the threshold estimation. The dependent variable of the selection equation takes the value of 1 when preferences were requested and zero otherwise. The results are different from previous results when the threshold value of the preferential tariff reduction was taken into account. The coefficient of duty difference becomes higher and more significant (in the previous results the variable was significant only at the ten per cent level). Furthermore, the coefficient of distance is smaller and similarly only significant at the ten per cent level. The variable measuring the hypothetical value of preferences is slightly smaller than in previous results. Finally, the sectoral dummies have smaller coefficients than those obtained by taking into account the threshold value. Overall, these results show that if low levels of duty reduction are included in the analysis, it is more the magnitude of duty reduction that matters and less other factors.

\section{Conclusions}

This paper investigated the impact of the preferential scheme on exports of non least-developed ACP countries to the EU. It also examined the importance of tariff reduction on requesting preferences by undertaking threshold estimation. While the analysis was limited to EU preferences towards non-least developed ACP countries, the main results are likely to be relevant for most preferential schemes.

Our results showed that the magnitude of preferences offered has a significant impact on the uptake of preferences. As intuitively expected, the higher the value of preferences offered, the higher the probability that preferences are requested. In the case of EU preferences offered to the ACP countries sectoral differences also play an important role. More precisely, in certain sectors the probability of requesting preferential access was less likely than in other sectors. On the other hand, preferences played significant role in improving market access to the EU in almost all sectors, with important differences between sectors. 
We also provided evidence that there exists a minimum value of preferences needed for traders to request preferences. Thus if the difference between preferential and third country tariff rates are lower than a certain amount, there are no incentives for traders to request preferences, since the costs of obtaining the preferences are expected to be higher than the benefits from obtaining the preferences. Our results additionally indicate that country specificities play a very important role in the decision whether requesting preferences or not and how much to import. These can reflect among other factors production costs, quality of products, competitiveness, quality of infrastructure, and institutional qualities of countries that play important role in the countries ability to benefit from the preferences offered by the EU. 


\section{References}

Anderson J.E. and E. van Wincoop, (2003), 'Gravity With Gravitas: A Solution to the Border Puzzle', The American Economic Review Vol. 93 (1), pp.170-192

Augier, P., Gasiorek, M. and Lai-Tong, C. (2005), 'The Impact of Rules of Origin in Trade Flows'. In The Origin of Goods: Rules of Origin in Regional Trade Agreements edited by Cadot, O., Estevadeordal, A., Suwa, A. and Verdier, T. CEPR/IADB/Oxford University Press, chap. 14.

Brenton, P. (2003), 'Integrating the Least Developed Countries into the World Trading System: The Current Impact of EU Preferences under Everything But Arms', World Bank Policy Research Working Paper 3018

Brenton, P. and Manchin, M. (2003), 'Making EU Trade Agreements Work: The Role of Rules of Origin', World Economy, May 2003, vol. 26, no. 5

Cadot, A. J. O., de Melo, J., Estevadeordal, A., Suwa-Eisenmann, A. and Tumurchudur, B., (2003) 'Rules of Origin in North-South Preferential Trading Arrangements with an Application to NAFTA’, CEPR Discussion Paper No. 4166.

Carrière, C. and de Melo, J., (2004), 'Are Different Rules of Origin Equally Costly? Estimates from NAFTA, CEPR Discussion Paper No. 4437

Davenport, Hewitt and Koning (1995), 'Europe's Preferred Partners? The Lomé Convention in World Trade', London, Overseas Development Institute

Deardorff, A (1995) 'Determinants of Bilateral Trade: Does Gravity Work in a Neoclassical World', Discussion Paper 382, Research Seminar in International Economics, University of Michigan.

Devault, J. M. (1996), 'Political Pressure and the US Generalized System of Preferences', Eastern Economic Journal, vol 22, pp.35-36 
ECDPM (2001a), 'Cotonou Infokit: From Lomé to Cotonou (13)’. Maastricht: ECDPM.

ECDPM (2001b), 'Cotonou Infokit: History and Evolution of ACP-EU Cooperation (3)', Maastricht: ECDPM

ECDPM (2001c), 'Helping the ACP Integrate into the World Economy. Setting the Agenda for Practical Research and Support', Maastricht: ECDPM

Estevadeordal, A. and Suominen, K. (2005), 'Rules of Origin: A World Map and Trade Effects'. In The Origin of Goods: Rules of Origin in Regional Trade Agreements edited by Cadot, O., Estevadeordal, A., Suwa, A. and Verdier, T. CEPR/IADB/Oxford University Press, chap. 4.

European Commission (2004), The European Union's Generalised System of Preferences GSP

Falvey, R. and Reed, G. (2002), 'Rules of Origin as Commercial Policy Instruments` . International Economic Review, Vol. 43, pp. 393-408

Hansen, B. E. (2000), ‘Sample Splitting and Threshold Estimation', Econometrica, 68, p. 575-603

Herin, J. (1986), 'Rules of Origin and Differences Between Tariff Levels in EFTA and in the EC, European Free Trade Association', Economic Affairs Department, Occasional Paper No. 13

Krishna, K. and Krueger, A. O. (1995), 'Implementing Free Trade Areas: Rules of Origin and Hidden Protection', NBER Working Paper No. W4983.

M. McQueen, C. Phillips, D. Hallam, A. Swinbank (1997), 'ACP-EU Trade and Aid Co-operation Post-Lomé IV', Brussels: ACP Secretariat, Document: ACP/28/065/97

Özden, C. and Reinhardt, E. (2004), 'The Perversity of Preferences: GSP and Developing Country Trade Policies, 1976-2000‘, World Bank Working Paper 2955 
Panagariya, A. (2002), 'EU Preferential Trade Policies and Developing Countries', World Economy, Vol. 25, No.10, November 2002, p. 1415-32

UNCTAD (1999), 'Quantifying the Benefits Obtained by Developing Countries from the Generalized System of Preferences', UNCTAD/ITCD/TSB/Misc.52, Geneva

UNCTAD (2000), 'Improving Market Access for Least Developed Countries', UNCTAD/DITC/TNCD/4, Geneva 
Figure 1 Share of imports from non-LDC ACP countries in total EU imports and value of imports

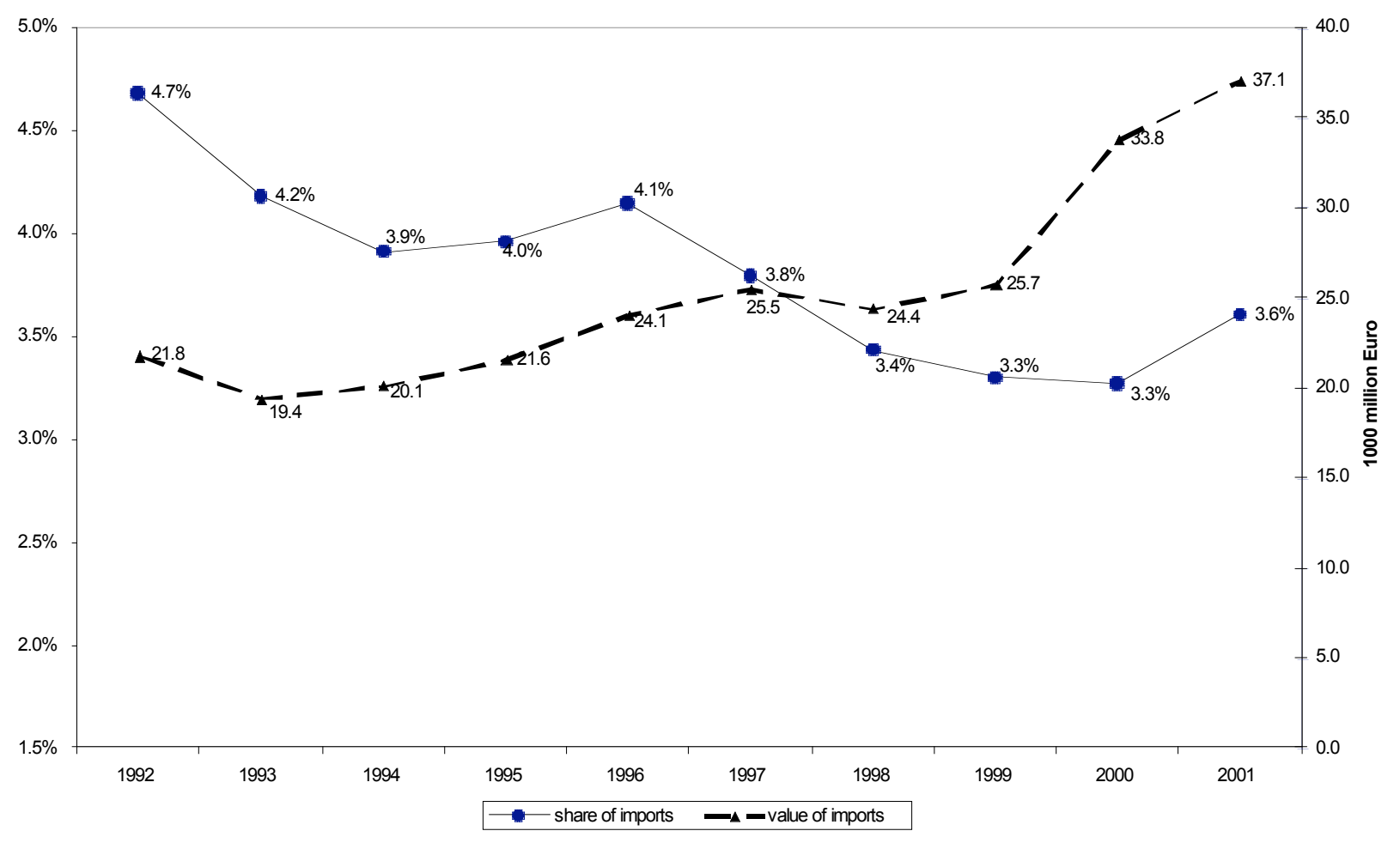


Table 1 Share of exports requested preferences as a percentage of total trade by countries in 2000

\begin{tabular}{lcc}
\hline & Cotonou & GSP \\
\hline Antigua.Barb & $25.0 \%$ & $0.0 \%$ \\
Bahamas & $87.6 \%$ & $0.0 \%$ \\
Barbados & $33.2 \%$ & $0.1 \%$ \\
Belize & $76.0 \%$ & $0.2 \%$ \\
Botswana & $87.7 \%$ & $0.1 \%$ \\
Cameroon & $89.2 \%$ & $0.1 \%$ \\
Congo & $41.0 \%$ & $0.0 \%$ \\
Dominica & $96.0 \%$ & $0.0 \%$ \\
Dominican R. & $55.3 \%$ & $0.5 \%$ \\
Fed.Micron. & $0.0 \%$ & $0.0 \%$ \\
Fiji & $79.0 \%$ & $0.4 \%$ \\
Gabon & $78.9 \%$ & $0.0 \%$ \\
Ghana & $57.2 \%$ & $0.2 \%$ \\
Grenada & $79.0 \%$ & $0.6 \%$ \\
Guyana & $64.5 \%$ & $0.0 \%$ \\
Ivory Coast & $70.2 \%$ & $0.3 \%$ \\
Jamaica & $72.7 \%$ & $0.1 \%$ \\
Kenya & $55.6 \%$ & $0.7 \%$ \\
Marshall Is. & $0.0 \%$ & $0.0 \%$ \\
Mauritius & $85.0 \%$ & $0.4 \%$ \\
Namibia & $87.2 \%$ & $2.7 \%$ \\
Nigeria & $56.3 \%$ & $0.5 \%$ \\
Palau & $0.0 \%$ & $0.0 \%$ \\
Papua N.G. & $81.6 \%$ & $0.5 \%$ \\
Senegal & $88.6 \%$ & $0.4 \%$ \\
Seychelles & $88.6 \%$ & $2.3 \%$ \\
South Africa & $21.2 \%$ & $14.4 \%$ \\
St Lucia & $98.5 \%$ & $0.0 \%$ \\
St Vincent & $58.1 \%$ & $0.0 \%$ \\
St.Ch.\&Nevis & $66.8 \%$ & $0.3 \%$ \\
Surinam & $64.9 \%$ & $0.3 \%$ \\
Swaziland & $53.6 \%$ & $3.0 \%$ \\
Tonga & $37.5 \%$ & $0.8 \%$ \\
Trinidad.Tob & $48.9 \%$ & $0.8 \%$ \\
Zimbabwe & $68.9 \%$ & $0.6 \%$ \\
Total & $49.4 \%$ & \\
& & \\
\hline
\end{tabular}


Table 2 Coverage of preferences

\begin{tabular}{|c|c|c|c|c|}
\hline & $\begin{array}{l}\text { Total exports to } \\
\text { the EU (Eur 1000) }\end{array}$ & $\begin{array}{l}\text { Exports of } 0 \text { duty } \\
\text { products }\end{array}$ & $\begin{array}{l}\text { Exports excluded } \\
\text { from preferences }\end{array}$ & $\begin{array}{c}\text { Exports eligible for } \\
\text { preferences }\end{array}$ \\
\hline Antigua,Barb & 351387 & $99 \%$ & $0 \%$ & $1 \%$ \\
\hline Bahamas & 608919 & $35 \%$ & $0 \%$ & $65 \%$ \\
\hline Barbados & 85112 & $48 \%$ & $31 \%$ & $21 \%$ \\
\hline Belize & 81037 & $8 \%$ & $36 \%$ & $56 \%$ \\
\hline Botswana & 1159120 & $91 \%$ & $0 \%$ & $9 \%$ \\
\hline Cameroon & 1735020 & $79 \%$ & $0 \%$ & $21 \%$ \\
\hline Congo & 384645 & $96 \%$ & $0 \%$ & $4 \%$ \\
\hline Dominica & 25622 & $10 \%$ & $0 \%$ & $90 \%$ \\
\hline Dominican R. & 313795 & $44 \%$ & $0 \%$ & $56 \%$ \\
\hline Fed.Micron. & 57 & $96 \%$ & $0 \%$ & $2 \%$ \\
\hline Fiji & 103679 & $3 \%$ & $92 \%$ & $5 \%$ \\
\hline Gabon & 1170255 & $94 \%$ & $0 \%$ & $6 \%$ \\
\hline Ghana & 1058739 & $56 \%$ & $0 \%$ & $44 \%$ \\
\hline Grenada & 33881 & $94 \%$ & $0 \%$ & $6 \%$ \\
\hline Guyana & 204075 & $26 \%$ & $67 \%$ & $6 \%$ \\
\hline Ivory Coast & 2054493 & $62 \%$ & $1 \%$ & $37 \%$ \\
\hline Jamaica & 569589 & $2 \%$ & $14 \%$ & $84 \%$ \\
\hline Kenya & 920723 & $42 \%$ & $5 \%$ & $53 \%$ \\
\hline Marshall Is. & 114954 & $100 \%$ & $0 \%$ & $0 \%$ \\
\hline Mauritius & 1287726 & $10 \%$ & $23 \%$ & $67 \%$ \\
\hline Namibia & 746864 & $49 \%$ & $0 \%$ & $51 \%$ \\
\hline Nigeria & 6371696 & $95 \%$ & $0 \%$ & $5 \%$ \\
\hline Palau & 64 & $100 \%$ & $0 \%$ & $0 \%$ \\
\hline Papua N.G. & 284574 & $55 \%$ & $0 \%$ & $45 \%$ \\
\hline Senegal & 450001 & $27 \%$ & $0 \%$ & $73 \%$ \\
\hline Seychelles & 189410 & $14 \%$ & $0 \%$ & $86 \%$ \\
\hline South Africa & 15377512 & $61 \%$ & $4 \%$ & $35 \%$ \\
\hline St Lucia & 48128 & $45 \%$ & $0 \%$ & $55 \%$ \\
\hline St Vincent & 153671 & $75 \%$ & $0 \%$ & $25 \%$ \\
\hline St.Ch.\&Nevis & 14057 & $2 \%$ & $81 \%$ & $18 \%$ \\
\hline Surinam & 153576 & $3 \%$ & $7 \%$ & $89 \%$ \\
\hline Swaziland & 148741 & $2 \%$ & $73 \%$ & $25 \%$ \\
\hline Tonga & 720 & $66 \%$ & $1 \%$ & $33 \%$ \\
\hline Trinidad,Tob & 408025 & $24 \%$ & $6 \%$ & $69 \%$ \\
\hline Zimbabwe & 778498 & $26 \%$ & $5 \%$ & $69 \%$ \\
\hline TOTAL & 37388365 & $64 \%$ & $4 \%$ & $31 \%$ \\
\hline
\end{tabular}


Table 3 Utilisation rate of Cotonou preferences by sectors (for eligible products)

\begin{tabular}{ccccc}
\hline Sectors & $\begin{array}{c}\text { Utilisation } \\
\text { rate }\end{array}$ & $\begin{array}{c}\text { Average difference } \\
\text { between MFN and } \\
\text { preferential tariffs }\end{array}$ & $\begin{array}{c}\text { Value of } \\
\text { exports }\end{array}$ & $\begin{array}{c}\text { Number of } \\
\text { observations }\end{array}$ \\
Agriculture & $62 \%$ & $15 \%$ & 4674556 & 4576 \\
Clothing & $83 \%$ & $12 \%$ & 903713 & 2723 \\
Footwear & $51 \%$ & $6 \%$ & 37605 & 431 \\
Machinery & $29 \%$ & $3 \%$ & 1449037 & 5108 \\
Mineral & $47 \%$ & $3 \%$ & 212573 & 85 \\
Textiles & $70 \%$ & $7 \%$ & 203393 & 1009 \\
Wood & $86 \%$ & $5 \%$ & 258164 & 738 \\
Other & $34 \%$ & $4 \%$ & 4490398 & 9015 \\
Total & $49 \%$ & $7 \%$ & 12229438 & 23685 \\
\hline
\end{tabular}

Table 4 Utilisation rate of Cotonou preferences by difference between MFN and preferential duty (for eligible products)

\begin{tabular}{cc}
\hline Difference between MFN and & Utilisation rate \\
ACP duty (in \%) & \\
$0-2$ & $30 \%$ \\
$2-3$ & $22 \%$ \\
$3-4$ & $63 \%$ \\
$4-5$ & $49 \%$ \\
$5-6$ & $43 \%$ \\
$6-7$ & $57 \%$ \\
$7-8$ & $60 \%$ \\
$8-9$ & $26 \%$ \\
$9-10$ & $20 \%$ \\
$10-11$ & $49 \%$ \\
$11-12$ & $80 \%$ \\
$12-13$ & $77 \%$ \\
$13-16$ & $58 \%$ \\
$16-20$ & $88 \%$ \\
$20-$ & $85 \%$ \\
\hline
\end{tabular}


Table 5 Correlation between utilisation rate of Cotonou preferences and the difference between MFN and preferential tariffs

\begin{tabular}{|c|c|}
\hline Countries & $\begin{array}{l}\text { Correlation coefficient (star indicates } \\
\text { correlation at least } 5 \% \text { significant) }\end{array}$ \\
\hline Antigua. Barb & $0.4606^{*}$ \\
\hline Bahamas & -0.0176 \\
\hline Barbados & $0.3672 *$ \\
\hline Belize & $0.3196^{*}$ \\
\hline Botswana & $0.6619^{*}$ \\
\hline Cameroon & $0.1969 *$ \\
\hline Congo & 0.0195 \\
\hline Dominica & 0.1329 \\
\hline Dominican R. & $0.1961 *$ \\
\hline Fed.Micron. & . \\
\hline Fiji & $0.4322 *$ \\
\hline Gabon & $0.1961^{*}$ \\
\hline Ghana & -0.0242 \\
\hline Grenada & $0.4509^{*}$ \\
\hline Guyana & 0.1415 \\
\hline Ivory Coast & $0.1219 *$ \\
\hline Jamaica & $0.3383^{*}$ \\
\hline Kenya & $0.2470 *$ \\
\hline Marshall Is. & . \\
\hline Mauritius & $0.2394 *$ \\
\hline Namibia & $0.3694^{*}$ \\
\hline Nigeria & 0.0034 \\
\hline Palau & . \\
\hline Papua N.G. & $0.3079 *$ \\
\hline Senegal & $0.3139 *$ \\
\hline Seychelles & $0.7156^{*}$ \\
\hline South Africa & $0.1445^{*}$ \\
\hline St Lucia & $0.3128 *$ \\
\hline St Vincent & $0.2925^{*}$ \\
\hline St.Ch.\&Nevis & 0.1619 \\
\hline Surinam & $0.2449 *$ \\
\hline Swaziland & $0.2758 *$ \\
\hline Tonga & -0.0339 \\
\hline Trinidad.Tob & 0.0328 \\
\hline Zimbabwe & $0.2672 *$ \\
\hline All countries & $0.0359 *$ \\
\hline
\end{tabular}


Figure 2.

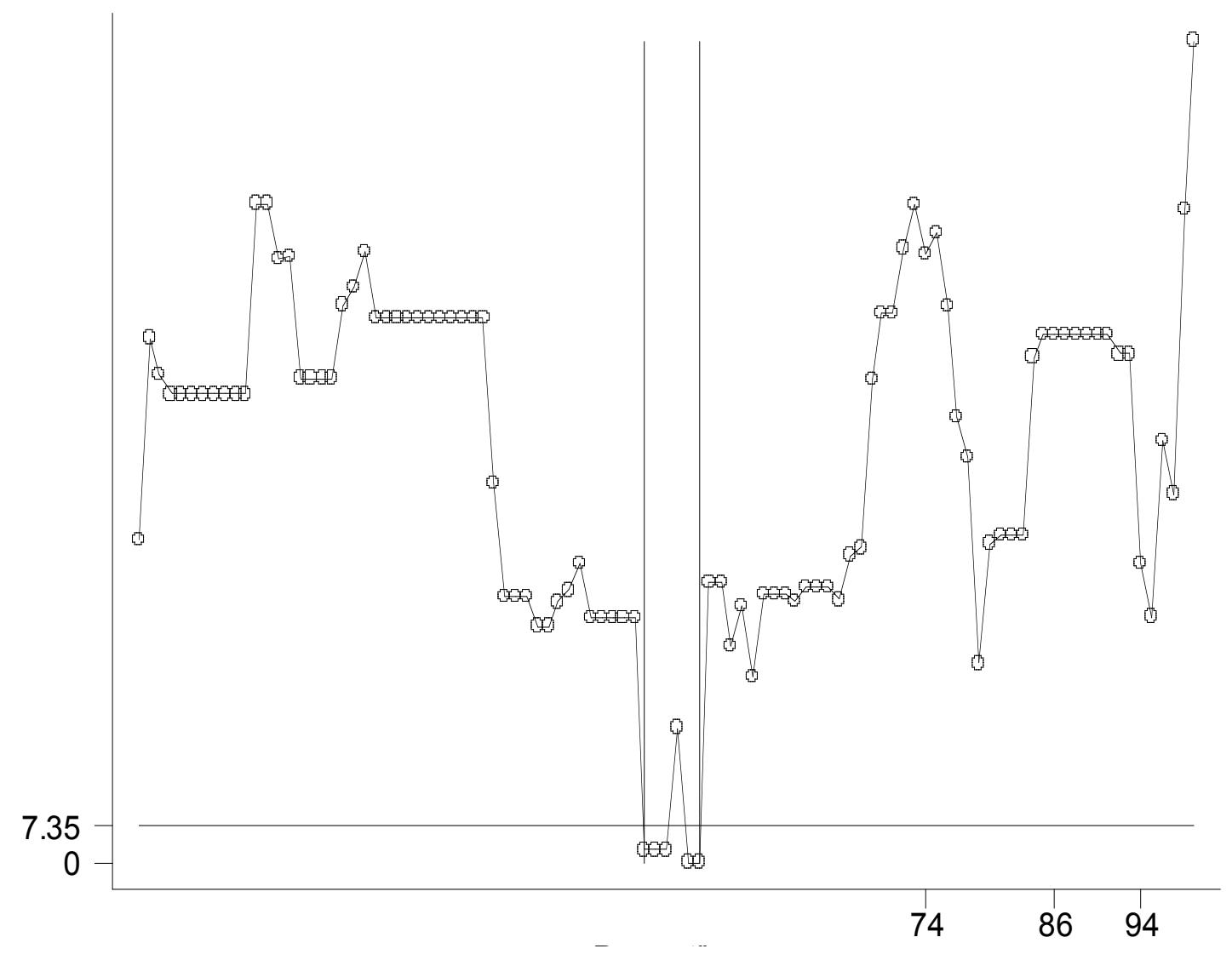


Table 6 Results of endogenous threshold regression

\begin{tabular}{|c|c|c|}
\hline & $(1)$ & $(2)$ \\
\hline Ldist & $\begin{array}{l}0.077 \\
(4.11)^{* *}\end{array}$ & $\begin{array}{l}-0.424 \\
(6.43)^{* *}\end{array}$ \\
\hline $\operatorname{lgdp}$ & $\begin{array}{l}0.035 \\
(12.69)^{* *}\end{array}$ & \\
\hline lpop & $\begin{array}{l}0.007 \\
(2.03)^{*}\end{array}$ & \\
\hline lgdpdecl & $\begin{array}{l}-0.215 \\
(13.10)^{* *}\end{array}$ & \\
\hline lpopdecl & $\begin{array}{l}0.279 \\
(16.67)^{* *}\end{array}$ & \\
\hline freedomidicator & $\begin{array}{l}-0.006 \\
(2.21)^{*}\end{array}$ & \\
\hline Frenchcolony & $\begin{array}{l}0.075 \\
(4.14)^{* *}\end{array}$ & \\
\hline NONfrenchcolony & $\begin{array}{l}0.008 \\
(0.92)\end{array}$ & \\
\hline SouthAfrica & $\begin{array}{l}-0.316 \\
(17.57)^{* *}\end{array}$ & \\
\hline DUMagri & $\begin{array}{l}0.285 \\
(26.87)^{* *}\end{array}$ & $\begin{array}{l}0.331 \\
(29.26)^{* *}\end{array}$ \\
\hline DUMtext & $\begin{array}{l}0.237 \\
(13.93)^{* *}\end{array}$ & $\begin{array}{l}0.219 \\
(13.04) * *\end{array}$ \\
\hline DUMfoot & $\begin{array}{l}0.131 \\
(5.36)^{* *}\end{array}$ & $\begin{array}{l}0.129 \\
(5.35)^{* *}\end{array}$ \\
\hline DUMmach & $\begin{array}{l}-0.199 \\
(21.56)^{* *}\end{array}$ & $\begin{array}{l}-0.163 \\
(19.42)^{* *}\end{array}$ \\
\hline DUMwood & $\begin{array}{l}0.449 \\
(22.16)^{* *}\end{array}$ & $\begin{array}{l}0.447 \\
(20.05)^{* *}\end{array}$ \\
\hline DUMmineral & $\begin{array}{l}0.047 \\
(0.87)\end{array}$ & $\begin{array}{l}0.114 \\
(2.13)^{*}\end{array}$ \\
\hline DUMcloth & $\begin{array}{l}0.243 \\
(18.53)^{* *}\end{array}$ & $\begin{array}{l}0.219 \\
(16.29)^{* *}\end{array}$ \\
\hline dutysmall & $\begin{array}{l}-0.455 \\
(1.39)\end{array}$ & $\begin{array}{l}-0.450 \\
(1.43)\end{array}$ \\
\hline dutyhigh & $\begin{array}{l}0.609 \\
(8.46)^{* *}\end{array}$ & $\begin{array}{l}0.479 \\
(6.50)^{* *}\end{array}$ \\
\hline difference & $\begin{array}{l}-0.252 \\
(7.38)^{* *}\end{array}$ & $\begin{array}{l}-0.190 \\
(4.66) * *\end{array}$ \\
\hline quota & & $\begin{array}{l}-0.094 \\
(2.76)^{* *}\end{array}$ \\
\hline Country fixed effects & & included \\
\hline LR & $\begin{array}{l}\operatorname{chi} 2(19)=6279.82 \\
(\text { Prob }>\text { chi2 }=0.0000)\end{array}$ & $\begin{array}{l}\operatorname{chi} 2(57)=9706.34(\text { Prob }>\operatorname{chi} 2= \\
0.0000)\end{array}$ \\
\hline Pseudo R2 & 0.2074 & 0.3209 \\
\hline Log likelihood & -12001.857 & -10270.878 \\
\hline Observations & 23684 & 23641 \\
\hline
\end{tabular}


Table 7 Results of Heckman estimation

\begin{tabular}{|c|c|c|c|c|c|c|c|c|c|c|}
\hline & \multicolumn{2}{|c|}{ (1) } & \multicolumn{2}{|c|}{ (2) } & \multicolumn{2}{|c|}{ (3) } & \multicolumn{2}{|c|}{ (4) } & \multicolumn{2}{|c|}{ (5) } \\
\hline & $\begin{array}{l}\text { utilisationr } \\
\text { ate }\end{array}$ & request & $\begin{array}{l}\text { utilisation } \\
\text { rate }\end{array}$ & request & $\begin{array}{l}\text { utilisation } \\
\text { rate }\end{array}$ & request & $\begin{array}{l}\text { utilisation } \\
\text { rate }\end{array}$ & request & $\begin{array}{l}\text { utilisation } \\
\text { rate }\end{array}$ & request \\
\hline Ldistance & -0.039 & & -0.045 & & -0.047 & & 0.079 & & 0.083 & \\
\hline & $(0.011)^{* *}$ & & $(0.013)^{* *}$ & & $(0.014)^{* *}$ & & $(0.053)$ & & $(0.053)$ & \\
\hline LGDP & $\begin{array}{l}0.005 \\
(0.003)\end{array}$ & $\begin{array}{l}0.098 \\
(0.009)^{* *}\end{array}$ & & & $\begin{array}{l}0.007 \\
(0.003)^{*}\end{array}$ & $\begin{array}{l}0.096 \\
(0.010)^{* *}\end{array}$ & & & & \\
\hline LGDP/POP & & & $\begin{array}{l}0.008 \\
(0.002)^{* *}\end{array}$ & $\begin{array}{l}0.043 \\
(0.008) * *\end{array}$ & & & & & & \\
\hline LPOP & & & & & $\begin{array}{l}-0.009 \\
(0.003)^{* *}\end{array}$ & $\begin{array}{l}0.020 \\
(0.010)\end{array}$ & & & & \\
\hline LPOPeu & & & & & $\begin{array}{l}0.049 \\
(0.016)^{* *}\end{array}$ & $\begin{array}{l}0.610 \\
(0.056)^{* *}\end{array}$ & & & & \\
\hline LGDP/POPeu & & & $\begin{array}{l}-0.074 \\
(0.016)^{* *}\end{array}$ & $\begin{array}{l}-0.527 \\
(0.054)^{* *}\end{array}$ & & & & & & \\
\hline LGDPeu & $\begin{array}{l}-0.031 \\
(0.003)^{* *}\end{array}$ & $\begin{array}{l}0.065 \\
(0.013)^{* *}\end{array}$ & & & $\begin{array}{l}-0.077 \\
(0.016)^{* *}\end{array}$ & $\begin{array}{l}-0.518 \\
(0.055)^{* *}\end{array}$ & & & & \\
\hline Freedom index & $\begin{array}{l}0.003 \\
(0.002)\end{array}$ & $\begin{array}{l}-0.017 \\
(0.008)^{*}\end{array}$ & $\begin{array}{l}0.006 \\
(0.002) * *\end{array}$ & $\begin{array}{l}0.023 \\
(0.007)^{* *}\end{array}$ & $\begin{array}{l}0.005 \\
(0.002)^{* *}\end{array}$ & $\begin{array}{l}-0.024 \\
(0.009)^{* *}\end{array}$ & & & & \\
\hline French colony & $\begin{array}{l}0.025 \\
(0.013)\end{array}$ & $\begin{array}{l}0.275 \\
(0.056)^{* *}\end{array}$ & $\begin{array}{l}0.009 \\
(0.013)\end{array}$ & $\begin{array}{l}0.360 \\
(0.055)^{* *}\end{array}$ & $\begin{array}{l}0.029 \\
(0.014)^{*}\end{array}$ & $\begin{array}{l}0.297 \\
(0.056) * *\end{array}$ & & & & \\
\hline $\begin{array}{l}\text { Non French } \\
\text { colony }\end{array}$ & 0.016 & -0.037 & 0.002 & 0.084 & 0.022 & 0.030 & & & & \\
\hline & $(0.008)^{*}$ & $(0.031)$ & $(0.008)$ & $(0.030)^{* *}$ & $(0.008)^{* *}$ & $(0.031)$ & & & & \\
\hline SouthAfrica & $\begin{array}{l}-0.222 \\
(0.015)^{* *}\end{array}$ & $\begin{array}{l}-1.034 \\
(0.051)^{* *}\end{array}$ & $\begin{array}{l}-0.203 \\
(0.009) * *\end{array}$ & $\begin{array}{l}-0.670 \\
(0.031)^{* *}\end{array}$ & $\begin{array}{l}-0.201 \\
(0.017)^{* *}\end{array}$ & $\begin{array}{l}-1.091 \\
(0.055)^{* *}\end{array}$ & & & & \\
\hline preferences & & $\begin{array}{l}0.201 \\
(0.004)^{* *}\end{array}$ & & $\begin{array}{l}0.199 \\
(0.004) * *\end{array}$ & & $\begin{array}{l}0.200 \\
(0.005)^{* *}\end{array}$ & & $\begin{array}{l}0.238 \\
(0.005)^{* *}\end{array}$ & & \\
\hline dutydifference & $\begin{array}{l}0.004 \\
(0.026)\end{array}$ & & $\begin{array}{l}0.010 \\
(0.026)\end{array}$ & & $\begin{array}{l}0.006 \\
(0.026)\end{array}$ & & $\begin{array}{l}0.006 \\
(0.026)\end{array}$ & & $\begin{array}{l}0.016 \\
(0.026)\end{array}$ & \\
\hline DUMagriculture & & $\begin{array}{l}0.960 \\
(0.029)^{* *}\end{array}$ & & $\begin{array}{l}0.952 \\
(0.029) * *\end{array}$ & & $\begin{array}{l}0.963 \\
(0.029) * *\end{array}$ & & $\begin{array}{l}1.132 \\
(0.032)^{* *}\end{array}$ & & \\
\hline DUMtextiles & & $\begin{array}{l}1.170 \\
(0.047)^{* *}\end{array}$ & & $\begin{array}{l}1.173 \\
(0.047)^{* *}\end{array}$ & & $\begin{array}{l}1.160 \\
(0.047)^{* *}\end{array}$ & & $\begin{array}{l}1.202 \\
(0.050)^{* *}\end{array}$ & & \\
\hline DUMfootwear & & $\begin{array}{l}0.604 \\
(0.076)^{* *}\end{array}$ & & $\begin{array}{l}0.584 \\
(0.076)^{* *}\end{array}$ & & $\begin{array}{l}0.586 \\
(0.076) * *\end{array}$ & & $\begin{array}{l}0.621 \\
(0.081)^{* *}\end{array}$ & & \\
\hline DUMmachinery & & $\begin{array}{l}-1.334 \\
(0.079)^{* *}\end{array}$ & & $\begin{array}{l}-1.312 \\
(0.079)^{* *}\end{array}$ & & $\begin{array}{l}-1.331 \\
(0.080)^{* *}\end{array}$ & & $\begin{array}{l}-1.323 \\
(0.082)^{* *}\end{array}$ & & \\
\hline DUMwood & & $\begin{array}{l}0.260 \\
(0.057)^{* *}\end{array}$ & & $\begin{array}{l}0.244 \\
(0.058)^{* *}\end{array}$ & & $\begin{array}{l}0.222 \\
(0.058) * *\end{array}$ & & $\begin{array}{l}0.111 \\
(0.063)\end{array}$ & & \\
\hline DUMmineral & & $\begin{array}{l}-0.815 \\
(0.246)^{* *}\end{array}$ & & $\begin{array}{l}-0.747 \\
(0.242)^{* *}\end{array}$ & & $\begin{array}{l}-0.809 \\
(0.244)^{* *}\end{array}$ & & $\begin{array}{l}-0.732 \\
(0.252)^{* *}\end{array}$ & & \\
\hline DUMclothing & & $\begin{array}{l}1.239 \\
(0.034)^{* *}\end{array}$ & & $\begin{array}{l}1.248 \\
(0.034)^{* *}\end{array}$ & & $\begin{array}{l}1.265 \\
(0.034) * *\end{array}$ & & $\begin{array}{l}1.290 \\
(0.037)^{* *}\end{array}$ & & \\
\hline agripref & & & & & & & & & & $\begin{array}{l}0.236 \\
(0.008) * *\end{array}$ \\
\hline textilepref & & & & & & & & & & $\begin{array}{l}0.341 \\
(0.023)^{* *}\end{array}$ \\
\hline footpref & & & & & & & & & & $\begin{array}{l}0.286 \\
(0.036)^{* *}\end{array}$ \\
\hline machinerypref & & & & & & & & & & $\begin{array}{l}0.332 \\
(0.012)^{* *}\end{array}$ \\
\hline woodpref & & & & & & & & & & $\begin{array}{l}0.184 \\
(0.020) * *\end{array}$ \\
\hline mineralpref & & & & & & & & & & $\begin{array}{l}0.083 \\
(0.046)\end{array}$ \\
\hline clothpref & & & & & & & & & & $\begin{array}{l}0.328 \\
(0.013) * *\end{array}$ \\
\hline Constant & $\begin{array}{l}1.811 \\
(0.126)^{* *}\end{array}$ & $\begin{array}{l}-3.682 \\
(0.300)^{* *}\end{array}$ & $\begin{array}{l}1.995 \\
(0.148)^{* *}\end{array}$ & $\begin{array}{l}4.010 \\
(0.543)^{* *}\end{array}$ & $\begin{array}{l}2.364 \\
(0.170)^{* *}\end{array}$ & $\begin{array}{l}1.790 \\
(0.589)^{* *}\end{array}$ & $\begin{array}{l}0.300 \\
(0.446)\end{array}$ & $\begin{array}{l}-0.202 \\
(0.062)^{* *}\end{array}$ & $\begin{array}{l}0.246 \\
(0.445)\end{array}$ & $\begin{array}{l}0.156 \\
(0.048)^{* *}\end{array}$ \\
\hline Observations & 23685 & 23685 & 23685 & 23685 & 23685 & 23685 & 23685 & 23685 & 23685 & 23685 \\
\hline
\end{tabular}

Standard errors in parentheses

*significant at $5 \%, * *$ significant at $1 \%$ 
Table 8 Results of Heckman estimation, marginal effects

\begin{tabular}{|c|c|c|c|c|c|c|c|c|c|c|}
\hline & \multicolumn{2}{|c|}{ (1) } & \multicolumn{2}{|c|}{ (2) } & \multicolumn{2}{|c|}{ (3) } & \multicolumn{2}{|c|}{ (4) } & \multicolumn{2}{|c|}{ (5) } \\
\hline & $\begin{array}{l}\text { Utilisation } \\
\text { rate }\end{array}$ & request & $\begin{array}{l}\text { Utilisation } \\
\text { rate }\end{array}$ & request & $\begin{array}{l}\text { Utilisation } \\
\text { rate }\end{array}$ & request & $\begin{array}{l}\text { Utilisation } \\
\text { rate }\end{array}$ & request & $\begin{array}{l}\text { Utilisation } \\
\text { rate }\end{array}$ & request \\
\hline Ldistance & $\begin{array}{l}-0.039 \\
(0.011)^{* *}\end{array}$ & & $\begin{array}{l}-0.045 \\
(0.013)^{* *}\end{array}$ & & $\begin{array}{l}-0.047 \\
(0.014)^{* *}\end{array}$ & & $\begin{array}{l}0.079 \\
(0.053)\end{array}$ & & $\begin{array}{l}0.083 \\
(0.053)\end{array}$ & \\
\hline LGDP & $\begin{array}{l}0.003 \\
(0.003)\end{array}$ & $\begin{array}{l}0.018 \\
(0.009)^{* *}\end{array}$ & & & $\begin{array}{l}0.005 \\
(0.003)^{*}\end{array}$ & $\begin{array}{l}0.018 \\
(0.010)^{* *}\end{array}$ & & & & \\
\hline LGDP/POP & & & $\begin{array}{l}0.007 \\
(0.002)^{* *}\end{array}$ & $\begin{array}{l}0.008 \\
(0.008)^{* *}\end{array}$ & & & & & & \\
\hline LPOP & & & & & $\begin{array}{l}-0.009 \\
(0.003)^{* *}\end{array}$ & $\begin{array}{l}0.004 \\
(0.010)\end{array}$ & & & & \\
\hline LPOPeu & & & & & $\begin{array}{l}0.039 \\
(0.016)^{* *}\end{array}$ & $\begin{array}{l}0.113 \\
(0.056)^{* *}\end{array}$ & & & & \\
\hline LGDP/POPeu & & & $\begin{array}{l}-0.066 \\
(0.016)^{* *}\end{array}$ & $\begin{array}{l}-0.099 \\
(0.054)^{* *}\end{array}$ & & & & & & \\
\hline LGDPeu & $\begin{array}{l}-0.032 \\
(0.003)^{* *}\end{array}$ & $\begin{array}{l}0.012 \\
(0.013)^{* *}\end{array}$ & & & $\begin{array}{l}-0.069 \\
(0.016)^{* *}\end{array}$ & $\begin{array}{l}-0.096 \\
(0.055)^{* *}\end{array}$ & & & & \\
\hline Freedom index & $\begin{array}{l}0.003 \\
(0.002)\end{array}$ & $\begin{array}{l}-0.003 \\
(0.008)^{*}\end{array}$ & $\begin{array}{l}0.005 \\
(0.002)^{* *}\end{array}$ & $\begin{array}{l}0.004 \\
(0.007)^{* *}\end{array}$ & $\begin{array}{l}0.006 \\
(0.002)^{* *}\end{array}$ & $\begin{array}{l}-0.004 \\
(0.009)^{* *}\end{array}$ & & & & \\
\hline French colony & $\begin{array}{l}0.021 \\
(0.013)\end{array}$ & $\begin{array}{l}0.059 \\
(0.056)^{* *}\end{array}$ & $\begin{array}{l}0.003 \\
(0.013)\end{array}$ & $\begin{array}{l}0.082 \\
(0.055)^{* *}\end{array}$ & $\begin{array}{l}0.024 \\
(0.014)^{*}\end{array}$ & $\begin{array}{l}0.064 \\
(0.056)^{* *}\end{array}$ & & & & \\
\hline $\begin{array}{r}\text { Non French } \\
\text { colony }\end{array}$ & $\begin{array}{l}0.017 \\
(0.008)^{*}\end{array}$ & $\begin{array}{l}-0.007 \\
(0.031)\end{array}$ & $\begin{array}{l}0.001 \\
(0.008)\end{array}$ & $\begin{array}{l}0.016 \\
(0.030)^{* *}\end{array}$ & $\begin{array}{l}0.022 \\
(0.008)^{* *}\end{array}$ & $\begin{array}{l}0.006 \\
(0.031)\end{array}$ & & & & \\
\hline SouthAfrica & $\begin{array}{l}-0.206 \\
(0.015)^{* *}\end{array}$ & $\begin{array}{l}-0.182 \\
(0.051)^{* *}\end{array}$ & $\begin{array}{l}-0.192 \\
(0.009) * *\end{array}$ & $\begin{array}{l}-0.12 \\
(0.031) * *\end{array}$ & $\begin{array}{l}-0.183 \\
(0.017)^{* *}\end{array}$ & $\begin{array}{l}-0.19 \\
(0.055) * *\end{array}$ & & & & \\
\hline preferences & & $\begin{array}{l}0.037 \\
(0.004)^{* *}\end{array}$ & & $\begin{array}{l}0.037 \\
(0.004)^{* *}\end{array}$ & & $\begin{array}{l}0.037 \\
(0.005)^{* *}\end{array}$ & & $\begin{array}{l}0.029 \\
(0.005)^{* *}\end{array}$ & & \\
\hline dutydifference & $\begin{array}{l}0.004 \\
(0.026)\end{array}$ & & $\begin{array}{l}0.010 \\
(0.026)\end{array}$ & & $\begin{array}{l}0.006 \\
(0.026)\end{array}$ & & $\begin{array}{l}0.006 \\
(0.026)\end{array}$ & & $\begin{array}{l}0.016 \\
(0.026)\end{array}$ & \\
\hline DUMagriculture & & $\begin{array}{l}0.248 \\
(0.029)^{* *}\end{array}$ & & $\begin{array}{l}0.247 \\
(0.029) * *\end{array}$ & & $\begin{array}{l}0.247 \\
(0.029) * *\end{array}$ & & $\begin{array}{l}0.23 \\
(0.032)^{* *}\end{array}$ & & \\
\hline DUMtextiles & & $\begin{array}{l}0.362 \\
(0.047)^{* *}\end{array}$ & & $\begin{array}{l}0.365 \\
(0.047)^{* *}\end{array}$ & & $\begin{array}{l}0.358 \\
(0.047)^{* *}\end{array}$ & & $\begin{array}{l}0.302 \\
(0.050)^{* *}\end{array}$ & & \\
\hline DUMfootwear & & $\begin{array}{l}0.157 \\
(0.076)^{* *}\end{array}$ & & $\begin{array}{l}0.151 \\
(0.076)^{* *}\end{array}$ & & $\begin{array}{l}0.15 \\
(0.076)^{* *}\end{array}$ & & $\begin{array}{l}0.119 \\
(0.081)^{* *}\end{array}$ & & \\
\hline DUMmachinery & & $\begin{array}{l}-0.161 \\
(0.079) * *\end{array}$ & & $\begin{array}{l}-0.161 \\
(0.079)^{* *}\end{array}$ & & $\begin{array}{l}-0.16 \\
(0.080)^{* *}\end{array}$ & & $\begin{array}{l}-0.101 \\
(0.082)^{* *}\end{array}$ & & \\
\hline DUMwood & & $\begin{array}{l}0.059 \\
(0.057)^{* *}\end{array}$ & & $\begin{array}{l}0.055 \\
(0.058)^{* *}\end{array}$ & & $\begin{array}{l}0.049 \\
(0.058)^{* *}\end{array}$ & & $\begin{array}{l}0.017 \\
(0.063)\end{array}$ & & \\
\hline DUMmineral & & $\begin{array}{l}-0.089 \\
(0.246)^{* *}\end{array}$ & & $\begin{array}{l}-0.086 \\
(0.242)^{* *}\end{array}$ & & $\begin{array}{l}-0.088 \\
(0.244)^{* *}\end{array}$ & & $\begin{array}{l}-0.051 \\
(0.252)^{* *}\end{array}$ & & \\
\hline DUMclothing & & $\begin{array}{l}0.364 \\
(0.034)^{* *}\end{array}$ & & $\begin{array}{l}0.37 \\
(0.034)^{* *}\end{array}$ & & $\begin{array}{l}0.373 \\
(0.034) * *\end{array}$ & & $\begin{array}{l}0.305 \\
(0.037)^{* *}\end{array}$ & & \\
\hline agripref & & & & & & & & & & $\begin{array}{l}0.050 \\
(0.008)^{* *}\end{array}$ \\
\hline textilepref & & & & & & & & & & $\begin{array}{l}0.072 \\
(0.023)^{* *}\end{array}$ \\
\hline footpref & & & & & & & & & & $\begin{array}{l}0.062 \\
(0.036)^{* *}\end{array}$ \\
\hline machinerypref & & & & & & & & & & $\begin{array}{l}0.071 \\
(0.012)^{* *}\end{array}$ \\
\hline woodpref & & & & & & & & & & $\begin{array}{l}0.040 \\
(0.020)^{* *}\end{array}$ \\
\hline mineralpref & & & & & & & & & & $\begin{array}{l}0.017 \\
(0.046)\end{array}$ \\
\hline clothpref & & & & & & & & & & $\begin{array}{l}0.069 \\
(0.013)^{* *}\end{array}$ \\
\hline Observations & 23685 & 23685 & 23685 & 23685 & 23685 & 23685 & 23685 & 23685 & 23685 & 23685 \\
\hline
\end{tabular}

Standard errors from Table 6 in parentheses

$*$ significant at $5 \%,{ }^{*}$ significant at $1 \%$ 
Table 9 Results of Heckman estimation including sectoral dummies in both equations

\begin{tabular}{|c|c|c|c|c|c|c|c|c|}
\hline & \multicolumn{2}{|c|}{ (1) } & \multicolumn{2}{|c|}{ (2) } & \multicolumn{2}{|c|}{ (3) } & \multicolumn{2}{|c|}{ (4) } \\
\hline Ldistance & $\begin{array}{l}\text { utilisationrate } \\
-0.033 \\
(0.012)^{* *}\end{array}$ & request & $\begin{array}{l}\text { utilisationrate } \\
-0.033 \\
(0.013)^{*}\end{array}$ & request & $\begin{array}{l}\text { utilisationrate } \\
-0.039 \\
(0.015)^{* *}\end{array}$ & request & $\begin{array}{l}\text { utilisationrate } \\
0.093 \\
(0.053)\end{array}$ & request \\
\hline LGDP & $\begin{array}{l}0.004 \\
(0.003)\end{array}$ & $\begin{array}{l}0.098 \\
(0.009)^{* *}\end{array}$ & & & $\begin{array}{l}0.006 \\
(0.003)^{*}\end{array}$ & $\begin{array}{l}0.096 \\
(0.010) * *\end{array}$ & & \\
\hline LGDP/pop & & & $\begin{array}{l}0.007 \\
(0.002)^{* *}\end{array}$ & $\begin{array}{l}0.043 \\
(0.008)^{* *}\end{array}$ & & & & \\
\hline LPOP & & & & & $\begin{array}{l}-0.008 \\
(0.003)^{*}\end{array}$ & $\begin{array}{l}0.020 \\
(0.010)^{*}\end{array}$ & & \\
\hline LGDPeu & $\begin{array}{l}-0.029 \\
(0.003) * *\end{array}$ & $\begin{array}{l}0.066 \\
(0.013)^{* *}\end{array}$ & & & $\begin{array}{l}-0.090 \\
(0.016)^{* *}\end{array}$ & $\begin{array}{l}-0.512 \\
(0.055)^{* *}\end{array}$ & & \\
\hline LPOPeu & & & & & $\begin{array}{l}0.064 \\
(0.016)^{* *}\end{array}$ & $\begin{array}{l}0.605 \\
(0.056) * *\end{array}$ & & \\
\hline LGDP/POPeu & & & $\begin{array}{l}-0.090 \\
(0.016)^{* *}\end{array}$ & $\begin{array}{l}-0.522 \\
(0.054)^{* *}\end{array}$ & & & & \\
\hline Freedom index & $\begin{array}{l}0.003 \\
(0.002)\end{array}$ & $\begin{array}{l}-0.017 \\
(0.008)^{*}\end{array}$ & $\begin{array}{l}0.006 \\
(0.002)^{* *}\end{array}$ & $\begin{array}{l}0.023 \\
(0.007)^{* *}\end{array}$ & $\begin{array}{l}0.006 \\
(0.002)^{* *}\end{array}$ & $\begin{array}{l}-0.024 \\
(0.009)^{* *}\end{array}$ & & \\
\hline French colony & $\begin{array}{l}0.027 \\
(0.013)^{*}\end{array}$ & $\begin{array}{l}0.276 \\
(0.056)^{* *}\end{array}$ & $\begin{array}{l}0.015 \\
(0.013)\end{array}$ & $\begin{array}{l}0.362 \\
(0.055)^{* *}\end{array}$ & $\begin{array}{l}0.033 \\
(0.014)^{*}\end{array}$ & $\begin{array}{l}0.298 \\
(0.056) * *\end{array}$ & & \\
\hline $\begin{array}{l}\text { Non French } \\
\text { colony }\end{array}$ & $\begin{array}{l}0.011 \\
(0.008)\end{array}$ & $\begin{array}{l}-0.035 \\
(0.031)\end{array}$ & $\begin{array}{l}0.001 \\
(0.008)\end{array}$ & $\begin{array}{l}0.086 \\
(0.030)^{* *}\end{array}$ & $\begin{array}{l}0.019 \\
(0.008)^{*}\end{array}$ & $\begin{array}{l}0.031 \\
(0.031)\end{array}$ & & \\
\hline SouthAfrica & $\begin{array}{l}-0.225 \\
(0.015)^{* *}\end{array}$ & $\begin{array}{l}-1.033 \\
(0.051)^{* *}\end{array}$ & $\begin{array}{l}-0.209 \\
(0.009)^{* *}\end{array}$ & $\begin{array}{l}-0.668 \\
(0.031)^{* *}\end{array}$ & $\begin{array}{l}-0.206 \\
(0.018)^{* *}\end{array}$ & $\begin{array}{l}-1.090 \\
(0.055)^{* *}\end{array}$ & & \\
\hline preferences & & $\begin{array}{l}0.202 \\
(0.004) * *\end{array}$ & & $\begin{array}{l}0.201 \\
(0.004)^{* *}\end{array}$ & & $\begin{array}{l}0.202 \\
(0.004) * *\end{array}$ & & $\begin{array}{l}0.240 \\
(0.005)^{* *}\end{array}$ \\
\hline dutydifference & $\begin{array}{l}0.015 \\
(0.026)\end{array}$ & & $\begin{array}{l}0.020 \\
(0.027)\end{array}$ & & $\begin{array}{l}0.017 \\
(0.026)\end{array}$ & & $\begin{array}{l}0.017 \\
(0.026)\end{array}$ & \\
\hline DUMagriclture & $\begin{array}{l}0.073 \\
(0.010)^{* *}\end{array}$ & $\begin{array}{l}0.963 \\
(0.029)^{* *}\end{array}$ & $\begin{array}{l}0.075 \\
(0.010)^{* *}\end{array}$ & $\begin{array}{l}0.955 \\
(0.029)^{* *}\end{array}$ & $\begin{array}{l}0.072 \\
(0.010)^{* *}\end{array}$ & $\begin{array}{l}0.965 \\
(0.029) * *\end{array}$ & $\begin{array}{l}0.067 \\
(0.010)^{* *}\end{array}$ & $\begin{array}{l}1.135 \\
(0.032)^{* *}\end{array}$ \\
\hline DUMtextiles & $\begin{array}{l}0.131 \\
(0.013)^{* *}\end{array}$ & $\begin{array}{l}1.180 \\
(0.047)^{* *}\end{array}$ & $\begin{array}{l}0.130 \\
(0.013) * *\end{array}$ & $\begin{array}{l}1.183 \\
(0.047)^{* *}\end{array}$ & $\begin{array}{l}0.130 \\
(0.013)^{* *}\end{array}$ & $\begin{array}{l}1.171 \\
(0.047)^{* *}\end{array}$ & $\begin{array}{l}0.129 \\
(0.013)^{* *}\end{array}$ & $\begin{array}{l}1.216 \\
(0.049) * *\end{array}$ \\
\hline DUMfootwear & $\begin{array}{l}0.086 \\
(0.024) * *\end{array}$ & $\begin{array}{l}0.614 \\
(0.076) * *\end{array}$ & $\begin{array}{l}0.086 \\
(0.024)^{* *}\end{array}$ & $\begin{array}{l}0.593 \\
(0.076)^{* *}\end{array}$ & $\begin{array}{l}0.084 \\
(0.024)^{* *}\end{array}$ & $\begin{array}{l}0.596 \\
(0.076) * *\end{array}$ & $\begin{array}{l}0.081 \\
(0.023) * *\end{array}$ & $\begin{array}{l}0.632 \\
(0.081)^{* *}\end{array}$ \\
\hline DUMmachinery & $\begin{array}{l}-0.141 \\
(0.046)^{* *}\end{array}$ & $\begin{array}{l}-1.337 \\
(0.080)^{* *}\end{array}$ & $\begin{array}{l}-0.142 \\
(0.046)^{* *}\end{array}$ & $\begin{array}{l}-1.315 \\
(0.080)^{* *}\end{array}$ & $\begin{array}{l}-0.141 \\
(0.046)^{* *}\end{array}$ & $\begin{array}{l}-1.334 \\
(0.080)^{* *}\end{array}$ & $\begin{array}{l}-0.140 \\
(0.045)^{* *}\end{array}$ & $\begin{array}{l}-1.328 \\
(0.083) * *\end{array}$ \\
\hline DUMwood & $\begin{array}{l}0.083 \\
(0.017)^{* *}\end{array}$ & $\begin{array}{l}0.265 \\
(0.057)^{* *}\end{array}$ & $\begin{array}{l}0.081 \\
(0.017)^{* *}\end{array}$ & $\begin{array}{l}0.248 \\
(0.058)^{* *}\end{array}$ & $\begin{array}{l}0.079 \\
(0.017)^{* *}\end{array}$ & $\begin{array}{l}0.227 \\
(0.058) * *\end{array}$ & $\begin{array}{l}0.075 \\
(0.018)^{* *}\end{array}$ & $\begin{array}{l}0.118 \\
(0.063)\end{array}$ \\
\hline DUMmineral & $\begin{array}{l}-0.047 \\
(0.088)\end{array}$ & $\begin{array}{l}-0.828 \\
(0.247)^{* *}\end{array}$ & $\begin{array}{l}-0.053 \\
(0.089)\end{array}$ & $\begin{array}{l}-0.761 \\
(0.244)^{* *}\end{array}$ & $\begin{array}{l}-0.052 \\
(0.088)\end{array}$ & $\begin{array}{l}-0.824 \\
(0.245)^{* *}\end{array}$ & $\begin{array}{l}-0.049 \\
(0.089)\end{array}$ & $\begin{array}{l}-0.747 \\
(0.254)^{* *}\end{array}$ \\
\hline DUMclothing & $\begin{array}{l}0.086 \\
(0.011)^{* *}\end{array}$ & $\begin{array}{l}1.243 \\
(0.033)^{* *}\end{array}$ & $\begin{array}{l}0.089 \\
(0.011)^{* *}\end{array}$ & $\begin{array}{l}1.252 \\
(0.033)^{* *}\end{array}$ & $\begin{array}{l}0.086 \\
(0.011)^{* *}\end{array}$ & $\begin{array}{l}1.270 \\
(0.034) * *\end{array}$ & $\begin{array}{l}0.088 \\
(0.011)^{* *}\end{array}$ & $\begin{array}{l}1.298 \\
(0.037)^{* *}\end{array}$ \\
\hline $\begin{array}{l}\text { Constant } \\
\text { County specific } \\
\text { dummies }\end{array}$ & $\begin{array}{l}1.630 \\
(0.133)^{* *}\end{array}$ & $\begin{array}{l}-3.703 \\
(0.300)^{* *}\end{array}$ & $\begin{array}{l}1.949 \\
(0.152)^{* *}\end{array}$ & $\begin{array}{l}3.957 \\
(0.544)^{* *}\end{array}$ & $\begin{array}{l}2.311 \\
(0.175)^{* *}\end{array}$ & $\begin{array}{l}1.715 \\
(0.589)^{* *}\end{array}$ & $\begin{array}{l}0.104 \\
(0.443) \\
\text { included }\end{array}$ & $\begin{array}{l}-0.204 \\
(0.062)^{* *} \\
\text { included }\end{array}$ \\
\hline Observations & 23685 & 23685 & 23685 & 23685 & 23685 & 23685 & 23685 & 23685 \\
\hline
\end{tabular}

Standard errors in parentheses

*significant at $5 \%,{ }^{* *}$ significant at $1 \%$ 
Table 10 Results of Heckman estimation without using the results of threshold estimation

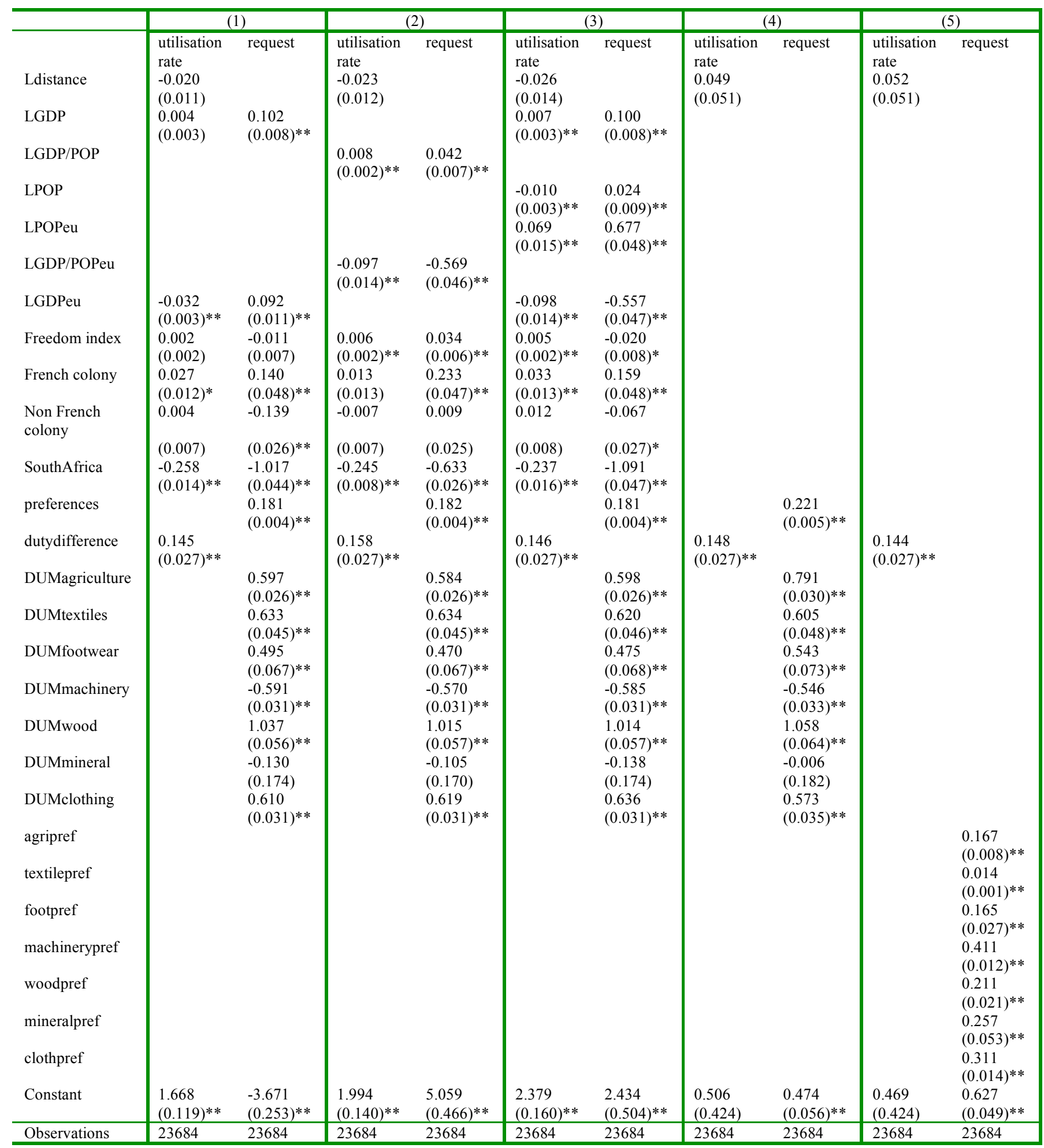

Standard errors in parentheses

*significant at 5\%,** significant at $1 \%$ 
Table 11 Correlation between the variables

\begin{tabular}{|c|c|c|c|c|c|c|c|c|c|}
\hline & Ldistance & LGDP & LGDPeu & LPOP & LPOPeu & LGDP/POP & LGDP/POPeu & $\begin{array}{l}\text { Freedom } \\
\text { index }\end{array}$ & $\begin{array}{l}\text { French } \\
\text { colony }\end{array}$ \\
\hline Ldistance & $0.3127^{*}$ & 1 & & & & & & & \\
\hline LGDP & $-0.0231 *$ & $-0.0706^{*}$ & 1 & & & & & & \\
\hline LGDPeu & $0.0133^{*}$ & $0.7075^{*}$ & $-0.0949 *$ & 1 & & & & & \\
\hline LPOP & $-0.0702 *$ & $-0.0758^{*}$ & $0.9757^{*}$ & $-0.0930^{*}$ & 1 & & & & \\
\hline LPOPeu & $0.4253^{*}$ & $0.6287^{*}$ & 0.005 & $-0.1048^{*}$ & -0.0042 & 1 & & & \\
\hline LGDP/POP & $0.2089^{*}$ & $0.0167 *$ & $0.1961^{*}$ & $-0.0165^{*}$ & $-0.0238^{*}$ & $0.0416^{*}$ & 1 & & \\
\hline LGDP/POPeu & $-0.5591^{*}$ & $-0.1927^{*}$ & $0.0433^{*}$ & $-0.0247^{*}$ & $0.0414 *$ & $-0.2440^{*}$ & 0.0124 & 1 & \\
\hline Freedom index & $-0.3507 *$ & $-0.0893 *$ & $0.1463 *$ & $-0.0525^{*}$ & $0.1423 *$ & $-0.0678^{*}$ & $0.0304 *$ & $0.2707^{*}$ & 1 \\
\hline $\begin{array}{l}\text { Non French } \\
\text { colony }\end{array}$ & $0.1286^{*}$ & $0.0340^{*}$ & $0.3390^{*}$ & $-0.0270^{*}$ & $0.2951^{*}$ & $0.0775^{*}$ & $0.2260 *$ & $-0.0529 *$ & $-0.1069^{*}$ \\
\hline South Africa & $0.6028^{*}$ & $0.7706^{*}$ & $-0.0952 *$ & $0.6055^{*}$ & $-0.0950 *$ & $0.4181^{*}$ & -0.0096 & $-0.5988^{*}$ & $-0.1910 *$ \\
\hline preferences & $0.0534^{*}$ & $0.0263^{*}$ & $0.1699^{*}$ & $-0.0287^{*}$ & $0.1794 *$ & $0.0685^{*}$ & $-0.0277^{*}$ & $-0.0332 *$ & -0.0076 \\
\hline $\begin{array}{c}\text { DUM } \\
\text { agriculture }\end{array}$ & $-0.1680^{*}$ & $-0.1057^{*}$ & $-0.0249^{*}$ & $-0.0504 *$ & $-0.0177 *$ & $-0.0934 *$ & $-0.0344^{*}$ & $0.1229 *$ & $0.0136^{*}$ \\
\hline DUM textiles & 0.0097 & $0.0411^{*}$ & $0.0269 *$ & $0.0296^{*}$ & $0.0327^{*}$ & $0.0252 *$ & $-0.0235^{*}$ & 0.0019 & -0.0018 \\
\hline DUM footwear & $-0.0221^{*}$ & $-0.0381^{*}$ & -0.0086 & 0.0126 & -0.0066 & $-0.0674 *$ & -0.0095 & $-0.0155^{*}$ & 0.0068 \\
\hline $\begin{array}{c}\text { DUM } \\
\text { machinery }\end{array}$ & 0.0047 & $0.0387^{*}$ & $0.0318^{*}$ & $0.0315^{*}$ & $0.0229 *$ & $0.0198 *$ & $0.0424 *$ & -0.0121 & $0.0480 *$ \\
\hline DUM wood & $-0.1599^{*}$ & $-0.0322^{*}$ & $-0.0215^{*}$ & 0.0061 & -0.0097 & $-0.0520^{*}$ & $-0.0548^{*}$ & $0.1288^{*}$ & $0.0322 *$ \\
\hline DUM mineral & -0.0005 & 0.0088 & 0.0019 & -0.0074 & 0.0049 & $0.0205^{*}$ & $-0.0133^{*}$ & -0.0041 & 0.0005 \\
\hline DUM cloth & $0.1097^{*}$ & $-0.0978^{*}$ & 0.0034 & $-0.1597^{*}$ & -0.0046 & $0.0380^{*}$ & $0.0363^{*}$ & $-0.0556^{*}$ & $-0.0366^{*}$ \\
\hline & $\begin{array}{c}\text { Non } \\
\text { French } \\
\text { colony }\end{array}$ & $\begin{array}{l}\text { South } \\
\text { Africa }\end{array}$ & preferences & $\begin{array}{c}\text { DUM } \\
\text { agriculture }\end{array}$ & $\begin{array}{c}\text { DUM } \\
\text { textiles }\end{array}$ & $\begin{array}{c}\text { DUM } \\
\text { footwear }\end{array}$ & $\begin{array}{c}\text { DUM } \\
\text { machinery }\end{array}$ & $\begin{array}{l}\text { DUM } \\
\text { wood }\end{array}$ & $\begin{array}{c}\text { DUM } \\
\text { mineral }\end{array}$ \\
\hline $\begin{array}{l}\text { Non French } \\
\text { colony }\end{array}$ & 1 & & & & & & & & \\
\hline South Africa & $0.0411^{*}$ & 1 & & & & & & & \\
\hline preferences & $0.1277 *$ & $0.0262^{*}$ & 1 & & & & & & \\
\hline $\begin{array}{c}\text { DUM } \\
\text { agriculture }\end{array}$ & $-0.0244 *$ & $-0.1474 *$ & $0.2424 *$ & 1 & & & & & \\
\hline DUM textiles & $0.0234^{*}$ & $0.0243^{*}$ & $0.0395 *$ & $-0.1032 *$ & 1 & & & & \\
\hline DUM footwear & -0.0013 & -0.0084 & $-0.0395 *$ & $-0.0666^{*}$ & $-0.0287 *$ & 1 & & & \\
\hline $\begin{array}{c}\text { DUM } \\
\text { machinery }\end{array}$ & $0.0204 *$ & $0.0476^{*}$ & $-0.2296^{*}$ & $-0.2566^{*}$ & $-0.1106^{*}$ & $-0.0714^{*}$ & 1 & & \\
\hline DUM wood & $-0.0431 *$ & $-0.0925^{*}$ & $0.0476^{*}$ & $-0.0878^{*}$ & $-0.0378 *$ & $-0.0244^{*}$ & $-0.0940^{*}$ & 1 & \\
\hline DUM mineral & $-0.0134 *$ & 0.0058 & 0.0046 & $-0.0294 *$ & -0.0127 & -0.0082 & $-0.0315^{*}$ & -0.0108 & 1 \\
\hline DUM cloth & 0.0114 & $-0.1098^{*}$ & $0.1325^{*}$ & $-0.1764 *$ & $-0.0760 *$ & $-0.0491^{*}$ & $-0.1890^{*}$ & $-0.0646^{*}$ & $-0.0216^{*}$ \\
\hline
\end{tabular}


Table 12 Description of variables

\begin{tabular}{|c|c|c|c|c|c|c|}
\hline Variable & Obs & Mean & Std. Dev. & Min & Max & \\
\hline ldistance & 23685 & 8.951 & 0.290 & 7.939 & 9.777 & Distance \\
\hline $\operatorname{lgdp}$ & 23685 & 16.694 & 2.240 & 8.590 & 18.663 & GDP of APC country \\
\hline lpop & 23685 & 9.500 & 1.751 & 2.996 & 11.774 & Population of ACP country \\
\hline lgdpdecl & 23685 & 20.449 & 0.987 & 16.909 & 21.451 & GDP of EU country \\
\hline lpopdecl & 23685 & 10.356 & 0.968 & 6.087 & 11.319 & Population of EU country \\
\hline Lgdp/pop & 23685 & 7.194 & 1.592 & 1.002 & 9.346 & GDP per capita of ACP country \\
\hline Lgdp/popdecl & 23685 & 10.093 & 0.217 & 9.401 & 10.823 & GDP per capita of EU country \\
\hline freedomidindicator & 23685 & 2.541 & 1.963 & 1.100 & 6.600 & Freedom index measuring the economic freedom of ACP country \\
\hline French colony & 23685 & 0.045 & 0.208 & 0.000 & 1.000 & Dummy for France and its ex-colonies \\
\hline Non French colony & 23685 & 0.194 & 0.395 & 0.000 & 1.000 & Dummy for non-French country-pairs with colonial links in the past \\
\hline SouthAfrica & 23685 & 0.434 & 0.496 & 0.000 & 1.000 & Dummy for South Africa \\
\hline Dutydifference & 23685 & 0.070 & 0.447 & 0.000 & 63.091 & Difference between preferential and MFN duty \\
\hline PREF & 23685 & -0.702 & 2.838 & -11.728 & 11.689 & Hypothetical value of preferences \\
\hline dumagri & 23685 & 0.193 & 0.395 & 0.000 & 1.000 & Dummy for agricultural products \\
\hline dumtext & 23685 & 0.043 & 0.202 & 0.000 & 1.000 & Dummy for textiles \\
\hline dumfoot & 23685 & 0.018 & 0.134 & 0.000 & 1.000 & Dummy for footwear \\
\hline dummach & 23685 & 0.216 & 0.411 & 0.000 & 1.000 & Dummy for machinery \\
\hline dumwood & 23685 & 0.031 & 0.174 & 0.000 & 1.000 & Dummy for wood products \\
\hline dummineral & 23685 & 0.004 & 0.060 & 0.000 & 1.000 & Dummy for mineral products \\
\hline dumcloth & 23685 & 0.115 & 0.319 & 0.000 & 1.000 & Dummy for clothing products \\
\hline agripref & 23685 & 0.136 & 1.399 & -11.728 & 11.689 & Hypothetical value of preferences for agriculture products \\
\hline textilepref & 23685 & -0.007 & 0.483 & -7.684 & 6.359 & Hypothetical value of preferences for footwear products \\
\hline footpref & 23685 & -0.028 & 0.393 & -8.217 & 6.741 & Hypothetical value of preferences for textiles products \\
\hline machinerypref & 23685 & -0.419 & 1.318 & -8.680 & 8.446 & Hypothetical value of preferences for machinery products \\
\hline woodpref & 23685 & 0.002 & 0.486 & -8.112 & 6.999 & Hypothetical value of preferences for wood products \\
\hline mineralpref & 23685 & -0.002 & 0.246 & -8.087 & 7.651 & Hypothetical value of preferences for mineral products \\
\hline clothpref & 23685 & 0.039 & 0.895 & -7.370 & 9.223 & Hypothetical value of preferences for clothing products \\
\hline
\end{tabular}

